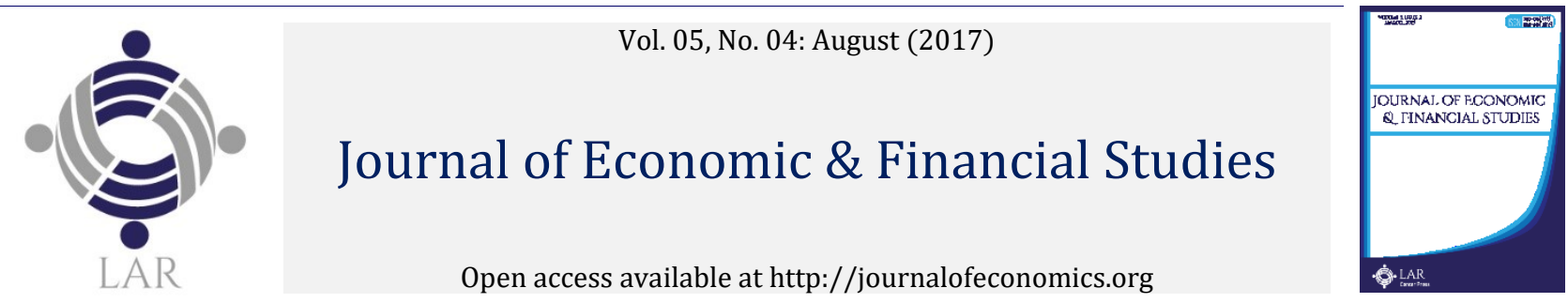

\title{
Sources of oil price shocks and external balance in Ghana
}

\author{
William Godfred Cantaha ${ }^{*}$, Camara K Obenga, William G Brafu-Insaidoo ${ }^{\mathrm{a}}$ \\ a University of Cape Coast, Ghana. \\ *Corresponding author’s email address: william.cantah@ucc.edu.gh
}

\section{A R T I C L E I N F O}

Received: 05-08-2017

Accepted: 25-08-2017

Available online: 15-09-2017

\section{Keywords:}

External balance;

Oil demand;

Structural vector autoregressive.

JEL Classification:

F31; Q34; Q43.

\begin{abstract}
A B S T R A C T
Faced with intermittent challenges of maintaining a stable external balance, several reports (see for example Bank of Ghana, 2005, 2009, 2015) attribute external imbalances to oil price shocks as a primary concern. Developments in the oil price literature however, suggest that effect oil price shock on macroeconomic variables depends on the source of the price shock. Hence, we examin the impact of oil price shocks on Ghana's external balance considering the source of the price shock. We employ a two-stage estimation which involved SVAR and ARDL. Results reveal that oil demand shocks tend to have a positive long run effect on external balance and oil market specific demand shock was also found to negative long run effect. Whereas oil supply shock was found to have a negative impact on trade balance and current account balance, its effect on capital account balance was positive. The implication of this result is that output in industrial commodities must be expanded following an oil price shock that is as a result of oil demand shock, since oil demand shock is usually an indication of expansion in global economic activities and leads increased demand for such commodities.
\end{abstract}

(C) 2017 The Authors. This is an open access article under the terms of the Creative Commons Attribution License 4.0, which allows use, distribution and reproduction in any medium, provided the original work is properly cited.

\section{Introduction}

The importance of crude oil to Ghana's economy cannot be overemphasised. It is an essential input of production and an important source of energy in Ghana. Crude oil provides about 46 percent of total energy needs of the country with the 54 percent provided by Biomass (40\%), Hydro (8\%) and Natural gas (7\%) (Energy Commission of Ghana, 2016). The importance of the commodity has increased with increase in size and growth of the Ghanaian economy. The consumption of crude oil in Ghana between 1972 and 2014 increased by an average of 100 percent per year as the consumption of the commodity rose from 750,000 tonnes in 1972 to over 4,000,000 tonnes by 2014(IEA, 2016).

Despite the key role of crude oil and its growing importance as well as the recent discovery of oil in the country, Ghana largely depends on imported crude oil to meet domestic demand for the commodity. In 2009 , for example, import of crude oil and its related products accounted for over 18 percent of merchandise imports. This increased to 20.5 percent in 2011 and steadily to over 25 percent by the end of 2014 (Bank of Ghana, 2012, 2015). Thus, changes in the price of crude oil could have implications for the external balance position of the economy.

Theoretically oil price hikes affect the external balance position of the economy through its effect imports. Hamilton (2008) noted that when demand for oil is inelastic, high crude oil prices would contribute to worsen the trade deficit position of the economy. This argument is collaborated by Kilian, Rebucci and Spatafora (2009) who further argued that oil price shocks could also affect the affect the capital account balance of an economy through its effect on asset prices. That is for a net oil importing economy oil price hikes could cause reduction in asset prices and dividends which could affect movement capital in and out of the domestic economy. However, Kilian 
(2009) and Kilian et al. (2009) noted that the effect of oil price on the external balance of an economy depends on the source of the price hike. They indicated depending on the source of the shock (demand or supply), the price hike could have a positive or negative impact on the external balance of the economy. Thus, the effect of oil price increases driven by a booming world economy (leading to increased demand for all industrial commodities including crude oil) on external balance would be different from oil price hikes that is driven disruptions in world oil productions or by changes in the precautionary demand for crude oil. This implies that the quantitative effect of an oil price shock on external balance would differ depending on the source of the price shock.

Notwithstanding the argument of Kilian et al (2009), the Bank of Ghana and other institutions (Including the Centre for Policy Analysis) have over the years attributed deterioration in the country's external balance position of the country to hikes in the price of crude oil. For example, the 2011 edition of the Bank of Ghana annual report, indicated that higher crude oil prices resulted a 47 percent increase in oil imports in 2011 (Bank of Ghana, 2012). This, according to the Bank, was a major contributor the traded deficit in 2011, which increased from US $\$ 2,962$ million in 2010 to US $\$ 3,052.3$ million at the end of 2011 . With the continues rise in the price of the commodity experienced between 2011 and 2013, the trade balance of Ghana worsened again in 2012 to about US $\$ 4,220.4$ million.

A critical examination of the movement in crude oil prices and Ghana's exports as well as imports seem to suggest that it is not always the case that increases in the price of crude oil necessarily leads to adverse external balance position. For example, with crude oil price increasing from US \$58 in 2007 to US\$64 in 2008 and then to US\$91 in 2009, Ghana's exports increased marginally by 0.5 percent in 2008 and then by 4.3 percent in 2009. During the same period imports declined by 2.2 percent. The increases in crude oi price during this period has been attributed to boom in the global economy (largely due boom the economies of Brazil, Russia, India, China and South Africa) (see Kilian, 2009 and Kilian et al. 2009). On the other increases in oil price from US\$23 in 2003 to US $\$ 28$ in 2004 and to US $\$ 38$ by the end of 2005 was associated with declines in Ghana's exports by 1.4, 2.9 and 11.3 in 2004, 2005 and 2006 respectively. Domestic imports during this period also increased. The high crude oil price during this period was largely attributed to the invasion of Iraq by the United States in 2003 (Kilian 2009).

Thus, there is the need to empirically analyse the extent which oil price shocks would affect Ghana's external balance position when source of the price shock is taken into account. A number of studies have examined the effect of oil price shocks on external balance key among them is the work of Kilian et al. (2009). Kilian et al. (2009) estimated the effects of demand and supply shocks in the crude oil markets on external balance of major oil importers and exporters and found that oil market specific demand shocks and oil supply shocks together accounted for about 89 percent of the fluctuations in the current account balance of oil exporters which was far more than that of oil importers. Though their study was the pioneering study to examine the differential impact of oil price shocks on external balance, the focus of their study did consider developing countries that are net importers of crude oil. The composition of imports and exports of developing countries are quite different that of developed economies as such, the effect oil price shocks on external balance of developing economies is likely to be different from that developed. In addition, their study only considered the short run effect of oil price shocks on external balance without considering the possibility of changes in effect in the long run.

Although Chuku, Akpan, Sam and Effiong (2011), used similar methodology to examine the effect of oil price shocks on the current account balance of the Nigerian economy, their study was based on a net oil exporting developing economy. The result of their study indicated that oil price shocks (supply \& Demand Shocks) had a positive impact on Nigeria's current account balance. Given the fact that crude oil is a major export in the Nigerian economy, the effect of oil price shocks on such an economy is likely to be different from a net oil importing economy like Ghana. More so, their study just like that of Kilian et al. (2009) only focused on the short run dynamics of the price shocks.

Unlike Chuku et al. (2011) and Kilian et al. (2009), Mucuk, Gerçeker and Ay (2013) focused on the effect of fluctuations in the price of oil on current account balance of Turkey and found that increases in the price of crude oil resulted in current account deficit. However, their study did not take into account the role of the source of the oil price shock which per the argument of Kilian et al. (2009) and Chuku et al. (2011) could have influence on how oil prices would affect the current account balance. Similar to the work of Mucuk et al. (2013), Huntington (2015) examined the relationship between oil price and current account balance of 91 countries which included Ghana using a panel estimation technique. Results obtained by Huntington (2015) was not much different from the result of Mucuk et al. (2013) for the Turkish economy. Huntington's (2015) study also suffered from the same problem associated with the work of Mucuk et al. (2013). Also, though this study, to some extent, focused on the Ghanaian economy, the fact that study was a cross country study makes it difficult to identify Ghana's peculiar situation in terms of how oil price shock affects the current account.

As a contribution to the literature on oil price and external balance, the current study sought to examine the impact of oil price shocks on Ghana's external balance taking into account the source of the price shock. This study unlike the existing study focuses on the Ghanaian economy whose export composition are quite different from countries studied in the literature. In addition, given the fact that Ghana is one of the destinations of foreign direct investment in Sub Saharan Africa, it would be quite interesting to examine the dynamic effect of changes in the oil market on the movement of capital in and out of the country. The study further contributes to the literature 
by examining the possible differences the effect of the price shock given the time horizon (whether short run or long run effect are the same.

The working hypothesis of the study is that, the effect of oil price shock on external balance of Ghana's depends on the source of the price shock. In addition, the study hypothesises that the effect of these shocks would vary between the short and long run. To achieve this, the study employs a two-stage estimation technique. First the study first estimated oil price shocks using a Structural Vector Autoregressive (SVAR) model. The restrictions the study placed on the SVAR model allowed for the netting out of the various sources of oil price shocks. We then estimated the effect these shocks on Ghana's external balance using the Autoregressive Distributed Lag (ARDL) model.

The rest of the study is organised as follows, section two discusses the methodology and data that was employed for the study. The section that follows provides a detailed discussion of the results and also provide some insights for policy. Section four provides conclusions for the study.

\section{Methodology and data}

\subsection{Methodology \\ 2.1.1 Theoretical model specification}

2.1.1.1 Trade balance

The study proxied external balance by using the trade balance and capital account balance. The theoretical model used in this study was based on the Imperfect Trade Substitution Model of Goldstein and Khan (1985), Rose (1991) and Rose and Yellen (1989). The imperfect trade substitution model is a two-country model of trade which is based on the assumption that the domestically produced goods and imported goods are imperfect substitutes. The model further assumes that the volume of imported goods by citizens of the domestic economy is positively related to domestic income and negatively related to relative import prices. The imperfect trade substitution model can, thus, be specified as;

$$
\begin{aligned}
& D_{Q M}=f\left(Y, p_{m}\right) \\
& D_{Q M}^{*}=f\left(Y^{*}, p_{m}^{*}\right)
\end{aligned}
$$

Where $D_{Q M}\left(D_{Q M}^{*}\right)$ is the quantity of goods imported by the domestic (foreign) economy; $Y\left(Y^{*}\right)$ is the level of income measured in domestic (foreign) output; $p_{m}$ is the relative import price of goods that are imported into the domestic economy and $P_{m}^{*}$ is the corresponding relative price of imports abroad. Equations (1) and (2) constitute the Marshallian demand functions, with relative income elasticities and price expected to be positive and negative in sign respectively.

In terms of the supply of exports, Rose and Yellen (1989) maintains that the supply of exports depends largely on the relative price of exportable goods. This is shown in the equations below.

$$
\begin{aligned}
& S_{Q X}=f\left(p_{x}\right) \\
& S_{Q X}^{*}=f\left(p_{x}^{*}\right)
\end{aligned}
$$

Where $S_{Q X}\left(S_{Q X}^{*}\right)$ is the supply of exports from the domestic (foreign) economy; $p_{x}$ represents the relative price of exports measured as a ratio of the domestic currency price of exported goods $\left(P_{x}\right)$ to domestic price level $(P)$; similarly, $p_{x}^{*}$ is analogously referred to as the relative price of foreign economy's exports, which is $P_{x}^{*}$ divided by $P^{*}$.

The domestic economy's relative import prices can be expressed as

$p_{m}=E \times \frac{P_{x}^{*}}{P}=\left(E \times \frac{P^{*}}{P}\right) \times\left(\frac{P_{x}^{*}}{P^{*}}\right) \equiv q \times p_{x}^{*}$

Where $E$ is the nominal exchange rate; consequently, the domestic currency of foreign exchange and $q\left(q=E \times \frac{P^{*}}{P}\right)$ captures the real exchange rate. Similarly, the relative price of foreign imports is given by

$p_{m}^{*}=\frac{P_{x}}{q}$

At equilibrium, transacted quantities and the relative prices of exports in each country are determined by the equilibrium conditions specified in equations (7) and (8)

$$
\begin{aligned}
& D_{Q M}=S_{Q X}^{*} \\
& D_{Q M}^{*}=S_{Q X}
\end{aligned}
$$

The value of the domestic economy's trade balance (TB) in real terms is the value of net exports in domestic currency divided by the domestic price level as specified in equation (9) 


$$
T B=\left(p_{x} \times D_{Q M}^{*}\right)-\left(q \times p_{x}^{*} \times D_{Q M}\right)
$$

Rose and Yellen (1989) argued that in the presence of capital flows, TB must not necessarily be equal to zero. Domestic demand for import however can be separated into oil imports and other imports. Oil imports are mainly influenced by activities in the oil. Other imports are mainly influenced by the fiscal balance position, terms of trade and activities in the oil market (see Bodenstein et al., 2011; Kilian et al., 2009). Equations (1) to (9) can be solved for levels of domestic exports and imports and their relative price ratios $p_{x}^{*}$ and $p_{x}$, taking into consideration the various factors that affect domestic demand for imports. Consequently, TB can be written as a partial reduced form as:

$T B=f\left(q, F B, T O T, O D S, O D S S, O S S, Y, Y^{*}\right)$

Where $q$ is real exchange rate, $F B$ is fiscal balance, TOT is terms of trade, ODS is oil demand shock, ODSS is the oil market specific demand shocks, OSS is oil supply shock and $Y$ and $Y^{*}$ are domestic and foreign income respectively.

\subsubsection{Capital account}

The theoretical basis of our capital account model is derived from the Mundell Fleming model on capital mobility.

$$
K A_{t}=k\left(r^{d}-r^{f}\right)=k\left(r^{*}\right), \quad k^{\prime}>0
$$

Where $K A_{t}$ is the capital account balance, $r^{d}$ is the domestic interest rate, $r^{f}$ is the interest rate for the rest of the world and $r^{*}$ is the interest rate differential between domestic and interest rate of the rest of the world.

\subsubsection{Empirical model specification}

2.1.2.1 Trade balance and oil price shocks

The imperfect substitution model of Rose (1991) and Rose and Yellen (1989) as discussed in the theoretical model specification above does not completely capture some key factors that could affect trade balance of a developing country like Ghana. As a result, the function specified in equation (10) is modified to capture variables that has been identified in the literature to affect trade balance in Ghana. A number of studies have identified interest rate, terms of trade and fiscal balance as key determinants of trade balance in Ghana (see for example, Akoto, 2016; Duasa, 2007; Sakyi \& Opoku, 2016). In addition, since crude oil is an essential component of Ghana's import commodities, it is key to also analyse the extent to which oil price shocks (taking into account the source of the price shock) affects Ghana's trade balance position. Hence, equation (10) is re-specified as:

$$
\begin{aligned}
& T B_{t}=f\left(q_{t}, Y_{t}, Y_{t}^{*}, r_{t}, F B_{t}, T^{T O T_{t}}, \text { ODS }_{t}, \text { ODSS }_{t}, \text { OSS }_{t}\right) \\
& T B_{t}=f\left(q_{t}, Y_{t}, Y_{t}^{*}, r_{t}, F B_{t}, \text { TOT }_{t} \text { OP }_{t}\right)
\end{aligned}
$$

Where $q, Y, Y^{*}$ are as previously defined, $r$ is short term interest rate, $F B$ is the fiscal balance, TOT is the terms of trade $O D S$ oil demand shock, ODSS oil market specific demand shock, $O S S$ oil supply shocks and $O P$ is the price of crude oil.

$$
\begin{aligned}
& T B_{t}=\alpha_{0}+\alpha_{1} L q_{t}+\alpha_{2} L Y_{t}+\alpha_{3} r_{t}+\alpha_{4} F B_{t}+\alpha_{5} L T O T_{t}+\alpha_{6} L Y_{t}^{*}+\alpha_{7} O D S_{t}+\alpha_{8} O D S S_{t}+\alpha_{9} O S S_{t}+\epsilon_{t} \\
& T B_{t}=\beta_{0}+\beta_{1} L q_{t}+\beta_{2} L Y_{t}+\beta_{3} r_{t}+\beta_{4} F B_{t}+\beta_{5} L T O T_{t}+\alpha_{6} L Y_{t}^{*}+\beta_{6} L O P_{t}+\varepsilon_{t}
\end{aligned}
$$

Where $\alpha_{i}$ and $\beta_{i}$ are parameters to be estimated, t is the time period, $\epsilon$ and $\varepsilon$ represents the error terms and $L$ represent the natural logarithm operator. All other variables are as previously defined.

With the exception of interest rate, fiscal balance and the measures of oil price shocks (ODS, ODSS and OSS), the natural log of each variable was used. This was done because variables such as domestic and foreign income are multiplicative in nature. Also, taking the natural log allows the variables to be converted to the same unit of measurement and helps in minimising the problem of heteroscedasticity (Gujarati, 2009).

\subsubsection{Capital account balance and oil price shocks}

To analyse the effect of oil price shocks on the capital account balance, we augment equation (11) to include other control variables since in the case of Ghana an interest rate differential may not be the only factor that could influence the flow of capital in and out of the economy. This is because the fiscal balance position of the country, the inflow of foreign investment, the exchange rate, income levels, capital account openness and domestic price levels are possible variables that could also possibly influence the capital account balance of Ghana (see Brafu-Insaidoo \& Biekpe, 2014; Cantah, Brafu-Insaidoo, Wiafe, \& Adams, 2016; Edwards, 1990). In addition, given the fact that oil price shocks has the capacity to affect the flow of investment into the country (see Kilian et al., 2009), we also include the measures of oil price shocks (i.e. ODS, ODSS, and OSS) in the model.

$$
K A_{t}=k\left(r_{t}^{*}, F D I_{t}, C A O_{t}, R E E R_{t}, F B_{t}, y_{t}, C P I_{t}, O D S_{t}, O D S S_{t} O S S_{t}\right)
$$


Where $Y_{t}, r_{t}^{*}, F B_{t} q_{t}, O D S_{t}, O D S S_{t} O S S_{t}$ are as previously defined, $F D I_{t}$ foreign direct investment as a percentage of GDP, $C A O_{t}$ capital account openness and $C P I_{t}$ is the consumer price index. Natural logs of some variables were taken based on the reasons alluded to earlier in this section. Hence the equation to be estimated is defined by

$$
K A_{t}=k_{0}+k_{1} r_{t}^{*}+k_{2} F D I_{t}+k_{3} C A O_{t}+k_{4} L q_{t}+k_{5} F B_{t}+k_{6} L Y_{t}+k_{8} O D S_{t}+k_{9} O D S S_{t}+k_{10} O S S_{t}+\mu_{t}
$$

Just as we did for trade balance, we estimate another model maintaining just the world price of crude oil rather than the various oil price shocks. Thus,

$$
K A_{t}=k_{0}+k_{1} r_{t}^{*}+k_{2} F D I_{t}+k_{3} C A O_{t}+k_{4} L q_{t}+k_{5} F B_{t}+k_{6} L Y_{t}+k_{7} L O P+\mu_{t}
$$

\subsubsection{Empirical procedure}

As indicated earlier, the study employs a two-stage approach in which we first construct oil demand and supply shocks that affects oil prices in the oil market. To achieve this, the study adopted the identification procedure of (Kilian, 2009). In the second stage of our estimation the study empirically examines the response of the two measures of external balance (Trade Balance and Capital Account Balance) using the bounds testing approach to cointegration. In the context of a regression, the constructed oil markets shocks become orthogonal variables as such they tend to be uncorrelated with other variables included in the second stage regression and their coefficient estimates are unbiased.

\subsubsection{The identification of sources of oil price shocks}

In order to identify the various sources of oil price shocks, the study specified an SVAR as

$A Y_{t}=B(L) Y_{t-1}+\varepsilon_{t}$

Where $Y_{t}$ is a vector that captures world crude oil production, measure of global economic activity and real price of crude oil in US dollars (full description of the variable is provided in the data section); $\varepsilon_{t}$ is the vector of mutually and serially uncorrelated structural innovations that can be economically interpreted. The structural shocks are derived by imposing exclusion restrictions on $A^{-1}$ in $e_{t}=A^{-1} \varepsilon_{t}$, where $e_{t}$ is a vector of errors in a VAR (see Kilian, 2009 and Kilian et al., 2009):

$Y_{t}=A^{-1} B(L) Y_{t-1}+A^{-1} \varepsilon_{t}$

Three main sources of oil price shocks are attributed as follows: $\varepsilon_{1 t}^{O S S}$,is shocks to world supply of crude oil (henceforth "oil supply shock"); $\varepsilon_{2 t}^{O D S}$ represents shocks to world economic activities (henceforth "oil demand shock"); and $\varepsilon_{3 t}^{O D S S}$ denotes oil market specific demand shock (henceforth "oil market specific demand shock"). The identification of $A^{-1}$ in equation (20) is realised by imposing the following exclusion restrictions

$$
\left(\begin{array}{c}
e_{1 t}^{\text {oilsupply }} \\
e_{2 t}^{\text {geademand }} \\
e_{3 t}^{\text {oilprice }}
\end{array}\right)=\left(\begin{array}{ccc}
a_{11} & 0 & 0 \\
a_{21} & a_{32} & 0 \\
a_{31} & a_{32} & a_{33}
\end{array}\right)\left(\begin{array}{c}
\varepsilon_{1 t}^{O S S} \\
\varepsilon_{2 t}^{O D S} \\
\varepsilon_{3 t}^{O D S S}
\end{array}\right)
$$

The identifying restrictions in equation (21) is based on the assumption that crude oil supply (world oil production) does not respond to oil demand and oil market specific demand shock within the same month. The study assumes a vertical short run supply. World economic activity driven by shocks that are specific to the oil market, but with a month lag. This restriction is consistent with the slow adjustment of world economic activity due to movements in crude oil prices. Lastly, the real price of oil is assumed to respond to shocks to both oil supply and economic activities within the same month. This restriction is reasonable, since any exogenous changes in oil supply or economic activity are immediately echoed in oil prices. Kilian (2009) provides a detailed explanation on these identification restrictions. The estimation of the SVAR was based on the work of Kilian (2009), hence the study used the first difference of the natural logarithm of world oil supply, the de-trended index of real global economic activity, and the natural logarithm of real oil prices.

\subsubsection{Estimation procedure}

Before examining the effect of sources of oil price shocks on Ghana's trade balance, we first examined the time series properties of the various variables specified in equations (14), (15), (16) and (17). The study employed the Augmented Dickey Fuller (ADF) test, the Philips Peron (PP) test and the KPSS unit root test to check the order of integration for all the variables used for the study. We also employed the Zivot and Andrew structural break unit root test to examine the existence of structural breaks in our dependent variable. The need to test for the existence of structural breaks in our dependent variables arises from the fact that Ghana has since its dependences undertaken a number of reforms related to trade and capital account.

\subsubsection{Cointegration test}

Given the fact that variables used for our analysis were a mixture of I(1) and I(0) variables, the study adopted the Autoregressive Distributed Lag Model (ARDL) developed by Pesaran, Shin, and Smith (2001) and Pesaran and Pesaran (1997), to examine the long run and short run dynamic effect of oil price shocks on Ghana's 
external balance. The ARDL approach to cointegration examines the existence of the long run relationship using the following unrestricted error correction models:

$$
\begin{aligned}
& \Delta T B_{t}=\alpha_{0}+\alpha_{1} T B_{t-1}+\alpha_{2} L q_{t}+\alpha_{3} L Y_{t}+\alpha_{4} r_{t}+\alpha_{5} F B_{t}+\alpha_{6} L T O T_{t}+\alpha_{7} L Y_{t}^{*}+\alpha_{8} O D S_{t}+\alpha_{9} O D S S_{t}+\alpha_{10} O S S_{t}+ \\
& \sum_{i=1}^{P} \phi_{1 i} \Delta T B_{t-i}+\sum_{i=1}^{P} \phi_{2 i} \Delta L q_{t-i}+\sum_{i=1}^{P} \phi_{3 i} \Delta L Y_{t-i}+\sum_{i=1}^{P} \phi_{4 i} \Delta r_{t-i}+\sum_{i=1}^{P} \phi_{5 i} \Delta F B_{t-i}+\sum_{i=1}^{P} \phi_{6 i} \Delta L T O T_{t-i}+ \\
& \sum_{i=1}^{P} \phi_{7 i} \Delta L Y_{t-i}^{*}+\sum_{i=1}^{P} \phi_{8 i} \Delta O D S_{t-i}+\sum_{i=1}^{P} \phi_{9 i} \Delta O D S S_{t-i}+\sum_{i=1}^{P} \phi_{10 i} \Delta O S S_{t-i}+v_{t} \\
& \Delta T B_{t}=\alpha_{0}+\alpha_{1} T B_{t-1}+L q_{t}+\alpha_{3} L Y_{t}+\alpha_{4} r_{t}+\alpha_{5} F B_{t}+\alpha_{6} L T O T_{t}+\alpha_{7} L Y_{t}^{*}+\alpha_{8} L O P_{t}+\sum_{i=1}^{P} \phi_{1 i} \Delta T B_{t-i}+ \\
& \sum_{i=1}^{P} \phi_{2 i} \Delta L q_{t-i}+\sum_{i=1}^{P} \phi_{3 i} \Delta L Y_{t-i}+\sum_{i=1}^{P} \phi_{4 i} \Delta r_{t-i}+\sum_{i=1}^{P} \phi_{5 i} \Delta F B_{t-i}+\sum_{i=1}^{P} \phi_{6 i} \Delta L T O T_{t-i}+\sum_{i=1}^{P} \phi_{7 i} \Delta L Y_{t-i}^{*}+ \\
& \sum_{i=1}^{P} \phi_{8 i} \Delta L O P_{t-i}+\mu_{t} \\
& \Delta K A_{t}=k_{0}+\lambda K A_{t-1}+k_{1} r_{t}^{*}+k_{2} F D I_{t}+k_{3} C A O_{t}+k_{4} L q_{t}+k_{5} F B_{t}+k_{6} L Y_{t}+k_{7} O D S_{t}+k_{8} O D S S_{t}+k_{9} O S S_{t}+ \\
& \sum_{i=1}^{P} \omega_{1 i} \Delta K A_{t-i}+\sum_{i=1}^{P} \omega_{2 i} \Delta K A_{t-i} \sum_{i=1}^{P} \omega_{3 i} \Delta r_{t-i}^{*}+\sum_{i=1}^{P} \omega_{4 i} \Delta F D I_{t-i}+\sum_{i=1}^{P} \omega_{5 i} \Delta C A O_{t-i}+\sum_{i=1}^{P} \omega_{6 i} \Delta L q_{t-i}+ \\
& \sum_{i=1}^{P} \omega_{7 i} \Delta F B_{t-i}+\sum_{i=1}^{P} \omega_{8 i} \Delta L Y_{t-i}+\sum_{i=1}^{P} \omega_{9 i} \Delta O D S_{t-i}+\sum_{i=1}^{P} \omega_{10 i} \Delta O D S S_{t-i}+\sum_{i=1}^{P} \omega_{11 i} \Delta O S S_{t-i}+\psi_{t} \\
& \Delta K A_{t}=k_{0}+\lambda K A_{t-1}+k_{1} r_{t}^{*}+k_{2} F D I_{t}+k_{3} C A O_{t}+k_{4} L q_{t}+k_{5} F B_{t}+k_{6} L Y_{t}+k_{7} L O P_{t}+\sum_{i=1}^{P} \omega_{1 i} \Delta K A_{t-i}+ \\
& +\sum_{i=1}^{P} \omega_{2 i} \Delta K A_{t-i}+\sum_{i=1}^{P} \omega_{3 i} \Delta r_{t-i}^{*}+\sum_{i=1}^{P} \omega_{4 i} \Delta F D I_{t-i}+\sum_{i=1}^{P} \omega_{5 i} \Delta C A O_{t-i}+\sum_{i=1}^{P} \omega_{6 i} \Delta L q_{t-i}+\sum_{i=1}^{P} \omega_{7 i} \Delta F B_{t-i}+ \\
& \sum_{i=1}^{P} \omega_{8 i} \Delta L Y_{t-i}+\sum_{i=1}^{P} \omega_{9 i} \Delta L O P_{t-i}+\psi_{t}
\end{aligned}
$$

Where $\Delta$ denotes the first difference operator, $P$ is the lag order selected by the Information Criterion used, $\alpha_{0}, \beta_{0}$, and $k_{0}$ are the drift parameters while $v_{t}, u_{t}, \mu_{t}, \psi_{t}$ are the error terms which are $N\left(0, \delta^{2}\right)$. The parameters $\phi, \varphi$, and $\omega$ are short-run parameters and $\alpha_{j i}, \beta_{j i}, k_{j i}$, and $\lambda$ are the long-run multipliers. All the variables are defined as before.

The study began by estimating equations (22), (23), (24) and (25) with the bounds test by employing the OLS method, which is normally the first procedure in the ARDL model. The F-test was used to test for the presence of long-run relationship among the variables in the equations stated above as follows: The null hypotheses of no long-run relationship among the variables in the stated equations above was tested against the alternative hypotheses of a long- run.

Given that, the asymptotic distribution of the F-statistic is non-standard without considering the independent variables being I (0) or I (1), Pesaran and Pesaran (1997) provided two sets of critical values for the different numbers of regressors (k), and whether the ARDL model contains an intercept and/or trend. Therefore, the calculated F-statistic was compared with these sets of critical values developed on the basis that the independent variables are $\mathrm{I}(\mathrm{d})$ (where $0 \leq d \leq 1$ ). When the calculated F-statistic falls outside the upper critical value, then a null hypothesis of no cointegration will be rejected regardless of whether the variables are I (0) or I (1) implying a long- run relationship between the variables.

However, if the F-statistic falls below the lower bound, then the null hypothesis of no cointegration cannot be rejected. If the F-statistic lies within the lower critical and upper critical bounds, the test is inconclusive and it depends on whether the underlying variables are I (0) or I (1). This necessitates the testing for unit roots on the variables under investigation (Pesaran \& Pesaran, 1997). Provided that cointegration has been established from the ARDL model, the long run and error correction estimates of the ARDL and their asymptotic standard errors are then obtained.

$$
\begin{aligned}
& T B_{t}=\alpha_{0}+\sum_{i=1}^{P} \alpha_{1} T B_{t-i}+\sum_{i=1}^{P} \alpha_{2} L q_{t-i}+\sum_{i=1}^{P} \alpha_{3} L Y_{t-i}+\sum_{i=1}^{P} \alpha_{4} r_{t-i}+\sum_{i=1}^{P} \alpha_{5} F B_{t-i}+\sum_{i=1}^{P} \alpha_{6} L T O T_{t-i}+ \\
& \sum_{i=1}^{P} \alpha_{7} L Y_{t-i}^{*}+\sum_{i=1}^{P} \alpha_{8} O D S_{t-i}+\sum_{i=1}^{P} \alpha_{9} O D S S_{t-i}+\sum_{i=1}^{P} \alpha_{10} O S S_{t-i}+\alpha_{11} T B D U M_{t}+\varepsilon_{\mathrm{t}} \\
& T B_{t}=\alpha_{0}+\sum_{i=1}^{P} \alpha_{1} T B_{t-i}+\sum_{i=1}^{P} \alpha_{2} L q_{t-i}+\sum_{i=1}^{P} \alpha_{3} L Y_{t-i}+\sum_{i=1}^{P} \alpha_{4} r_{t-i}+\sum_{i=1}^{P} \alpha_{5} F B_{t-i}+\sum_{i=1}^{P} \alpha_{6} L T O T_{t-i}+ \\
& \sum_{i=1}^{P} \alpha_{7} L Y_{t-i}^{*}+\sum_{i=1}^{P} \alpha_{8} L O P_{t-i}++\alpha_{9} T B D U M_{t}+\varepsilon_{\mathrm{t}} \\
& K A_{t}=k_{0}+\sum_{i=1}^{P} \lambda K A_{t-i}+\sum_{i=1}^{P} k_{1} r_{t-i}^{*}+\sum_{i=1}^{P} k_{2} F D I_{t-i}+\sum_{i=1}^{P} k_{3} C A O_{t-i}+\sum_{i=1}^{P} k_{4} L q_{t-i}+\sum_{i=1}^{P} k_{5} F B_{t-i}+ \\
& \sum_{i=1}^{P} k_{6} L Y_{t-i}+\sum_{i=1}^{P} k_{7} O D S_{t-i}+\sum_{i=1}^{P} k_{8} O D S S_{t-i}+\sum_{i=1}^{P} \beta_{9} O S S_{t-i}+\beta_{10} K A D U M_{t}+\mu_{t}
\end{aligned}
$$




$$
\begin{aligned}
& K A_{t}=k_{0}+\sum_{i=1}^{P} \lambda K A_{t-i}+\sum_{i=1}^{P} k_{1} r_{t-i}^{*}+\sum_{i=1}^{P} k_{2} F D I_{t-i}+\sum_{i=1}^{P} k_{3} C A O_{t-i}+\sum_{i=1}^{P} k_{4} L q_{t-i}+\sum_{i=1}^{P} k_{5} F B_{t-i}+ \\
& \sum_{i=1}^{P} k_{6} L Y_{t-i}+\sum_{i=1}^{P} k_{7} L O P_{t-i}+\beta_{10} K A D U M_{t}+\mu_{t}
\end{aligned}
$$

The ARDL error correction representation of the series is also estimated as

$$
\begin{aligned}
& \Delta T B_{t}=\sum_{i=1}^{P} \phi_{1 i} \Delta T B_{t-i}+\sum_{i=1}^{P} \phi_{2 i} \Delta L q_{t-i}+\sum_{i=1}^{P} \phi_{3 i} L Y_{t-i}+\sum_{i=1}^{P} \phi_{4 i} \Delta r_{t-i}+\sum_{i=1}^{P} \phi_{5 i} \Delta F B_{t-i}+\sum_{i=1}^{P} \phi_{6 i} \Delta L T O T_{t-i} \\
& +\sum_{i=1}^{P} \phi_{7 i} \Delta L Y_{t-i}^{*}+\sum_{i=1}^{P} \phi_{8 i} \Delta O D S_{t-i}+\sum_{i=1}^{P} \phi_{9 i} \Delta O D S S_{t-i}+\sum_{i=1}^{P} \phi_{10 i} \Delta O S S_{t-i}+\phi_{11} T B D U M_{t}+\xi E C T_{t-1}+v_{t}(30) \\
& \Delta T B_{t}=\sum_{i=1}^{P} \phi_{1 i} \Delta T B_{t-i}+\sum_{i=1}^{P} \phi_{2 i} \Delta L q_{t-i}+\sum_{i=1}^{P} \phi_{3 i} L Y_{t-i}+\sum_{i=1}^{P} \phi_{4 i} \Delta r_{t-i}+\sum_{i=1}^{P} \phi_{5 i} \Delta F B_{t-i} \sum_{i=1}^{P} \phi_{6 i} \Delta L T O T_{t-i}+ \\
& \sum_{i=1}^{P} \phi_{7 i} \Delta L Y_{t-i}^{*}+\sum_{i=1}^{P} \phi_{8 i} \Delta L O P_{t-i}+T B D U M_{t}+\xi E C T_{t-1}+v_{t} \\
& \Delta K A_{t}=\sum_{i=1}^{P} \omega_{1 i} \Delta K A_{t-i}+\sum_{i=1}^{P} \omega_{2 i} \Delta K A_{t-i}+\sum_{i=1}^{P} \omega_{3 i} \Delta r_{t-i}^{*}+\sum_{i=1}^{P} \omega_{4 i} \Delta F D I_{t-i}+\sum_{i=1}^{P} \omega_{5 i} \Delta C A O_{t-i}+ \\
& \sum_{i=1}^{P} \omega_{6 i} \Delta L q_{t-i}+\sum_{i=1}^{P} \omega_{7 i} \Delta F B_{t-i}+\sum_{i=1}^{P} \omega_{8 i} \Delta L Y_{t-i}+\sum_{i=1}^{P} \omega_{9 i} \Delta O D S_{t-i}+\sum_{i=1}^{P} \omega_{10 i} \Delta O D S S_{t-i}+\sum_{i=1}^{P} \omega_{11 i} \Delta O S S_{t-i} \\
& +\omega_{12} K A D U M_{t}+\xi E C T_{t-1}+\psi_{t}
\end{aligned}
$$

$$
\begin{aligned}
& K A_{t}=\sum_{i=1}^{P} \omega_{1 i} \Delta K A_{t-i}+\sum_{i=1}^{P} \omega_{2 i} \Delta K A_{t-i}+\sum_{i=1}^{P} \omega_{3 i} \Delta r_{t-i}^{*}+\sum_{i=1}^{P} \omega_{4 i} \Delta F D I_{t-i}+\sum_{i=1}^{P} \omega_{5 i} \Delta C A O_{t-i}+\sum_{i=1}^{P} \omega_{6 i} \Delta L q_{t-i} \\
& +\sum_{i=1}^{P} \omega_{7 i} \Delta F B_{t-i}+\sum_{i=1}^{P} \omega_{8 i} \Delta L Y_{t-i}+\sum_{i=1}^{P} \omega_{9 i} \Delta L O P_{t-i}+\omega_{12} K A D U M_{t}+\xi E C T_{t-1}+\psi_{t}
\end{aligned}
$$

Where $\xi$ is the speed of adjustment of the parameter to long-run equilibrium following a shock to the system and $E C T_{t-1}$ is the residuals obtained from the long run equations. The coefficient of the lagged error correction term $\xi$ is expected to be negative and statistically significant to further confirm the existence of a cointegrating relationship among the variables in the model.

\subsection{Data description and source}

The data sets for the present study are mainly sourced from secondary sources. The dataset employed for the study was mainly time series in nature and ranges from monthly to quarterly series. Data used for the empirical work on oil price shocks and external balance ranged from 1980: Q1 to 2015: Q4. Data on the measures of external balance was sourced from the World Bank's World Development Indicators (WDI), the United Nations Conference on Trade and Development (UNCTAD) statistics as well as various editions of the State of the Ghanaian Economy by the Centre for Policy Analysis (CEPA), Ghana. Data on GDP, Terms of Trade and World Income were also obtained from the WDI. Data on Fiscal Balance was obtained from various editions of the State of the Ghanaian economy by Institute for Social and Statistical Research (ISSER), University of Ghana and Budget Statements of the Ministry of Finance, Ghana. Quarterly data on real effective exchange rate was obtained from the Brugel Institute and finally data on interest rate was obtained in monthly series from the Bank of Ghana (BoG). Monthly data on the LIBOR rate was obtained from the website of the Federal Reserve Bank of St. Louis. The study then used the average interest rate for each quarter for our estimation. Annual series were converted to quarterly series using the cubic spline interpolation method. Data on world production of crude oil which was used as proxy for oil supply was obtained from the US Energy Information Administration website. Also, data on World Economic Activity (WEA) measured the changes in output of the industrial sector of the world economy. Data on WEA was sourced from the work of Kilian (2009). Finally, data on crude oil price was obtained from the World Bank's Global Economic Monitor (GEM) commodity series.

\section{Empirical analysis}

\subsection{Unit roots test results}

Table 1 presents the unit roots test results for all the variables employed for the estimation. The study presented test results from ADF, PP and KPSS in order to ensure that the test results for the stationarity analysis are robust. Results from the ADF test indicates that domestic interest rate $\left(r_{t}\right)$, interest rate differential $\left(r_{t}^{*}\right)$, the natural log of consumer price index $\left(L C P I_{t}\right)$ and all the measures of oil price shocks $\left(O D S_{t}, O D S S_{t}\right.$ and $\left.O S S_{t}\right)$ are all integrated of the order zero (I (0)). All other variables are integrated of the order one (I (1)).

Contrary to the results from the ADF test, the PP test indicated that $r_{t}$ and $r_{t}^{*}$ were both integrated of order one. The results from the PP test however confirmed the results of the ADF test on the stationarity of the measures of oil price shocks. All other variables, with the exception of capital account balance (KA), world income (WY), LCPI and the measures of oil price shocks were integrated of order one per the PP test. 
The KPSS test, unlike the ADF and the PP test has a null hypothesis of stationarity and an alternative hypothesis of non-stationarity. Hence with respect to the KPSS test, a rejection of the null hypothesis does not imply the absence of unit root, but rather the presence of it. An examination of the KPSS test in Table 3B indicates that KA, $r_{t}^{*}, r_{t}$, the log of terms of trade, WY, capital account openness (CAO), LCPI and all the measures of oil price shocks are stationary at levels. The rest of the variables employed in the estimation process are stationary only after first difference.

The results of the unit root test indicate that the variables employed for the estimation of the effect of oil price shocks on external balance have two different order of integration (I(0) and I(1)), hence ARDL model would be more appropriate for our analysis.

$\underline{\text { Table 1: Stationarity test }}$

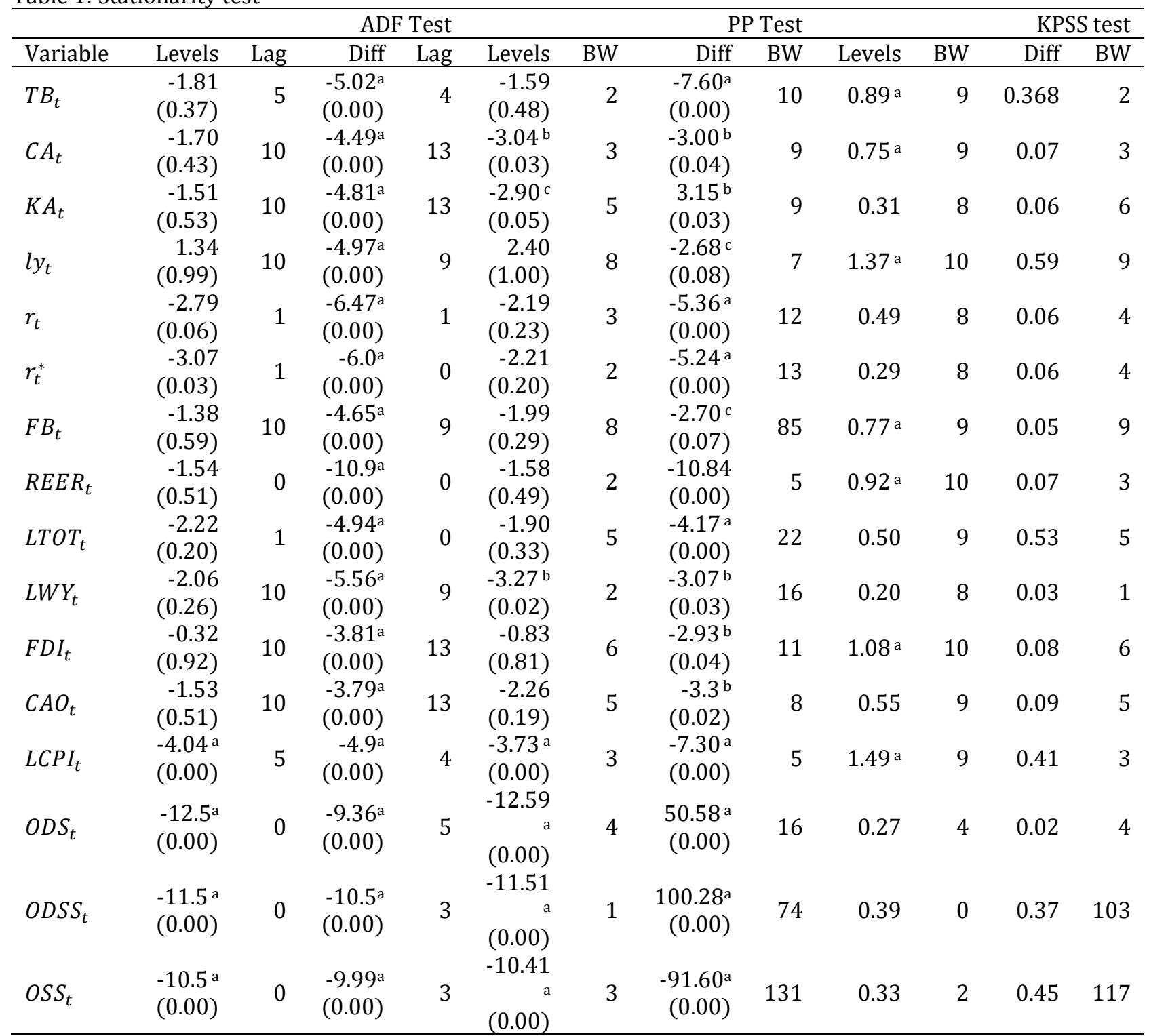

Note: Diff represents difference, ${ }^{\mathrm{a}}$, ${ }^{\mathrm{b}}$, and ${ }^{\mathrm{c}}$ denotes significance level at 1\%, 5\% and 10\% respectively. Numbers in brackets are P-Values. Lag and BW are the lag length and Bandwidth respectively. The respective critical values for the KPSS at $1 \%, 5 \%$ and $10 \%$ test are $0.739,0.463$ and 0.347 .

Source: Author's Computation using Eviews 9

\subsection{Timing of structural breaks of dependent variables}

Table 2 presents results of the Zivot-Andrews unit root test for both stationarity and the existence of structural breaks. The results of the stationarity test based on the Zivot-Andrews test indicates that all our dependent variables are stationary around one structural break. This gives contrary results obtained for the ADF unit root test. The result is however consistent with the test results obtained from the PP test for Capital Account balance.

Table 2 also presents the various break points in TB, and KA that could correspond to a number of events. The results of the test could also indicate the significance of some policy initiatives undertaken by the country to improve on its external balance position. The result of the Zivot-Andrews test for trade balance for example 
identifies the second quarter of 2008 as a break point. 2008 was the year the global economy experienced record increases in energy and food prices. This is corroborated by the Bank of Ghana quarterly bulleting which indicated the trade balance of the country deteriorated by 36 percent in the second quarter of 2008 when compared to the same quarter in 2007 (Bank of Ghana, 2008a). This still occurred despite the strong export performance that same quarter. The Bank of Ghana attributed this development to the hikes in energy and food prices.

Table 2: Structural breaks and unit root test for dependent variables

\begin{tabular}{lrrrrrr}
\hline Variable & Intercept & Break & Trend & Break & Both & Break \\
\hline \multirow{2}{*}{$T B_{t}$} & $-1.52^{\mathrm{c}}$ & \multirow{2}{*}{$2008 \mathrm{Q} 2$} & $-3.95^{\mathrm{a}}$ & \multirow{2}{*}{$2005 \mathrm{Q} 1$} & $-4.00^{\mathrm{c}}$ & \multirow{2}{*}{$(0.00)$} \\
& $(0.06)$ & & & & $(0.07)$ & \\
$K A_{t}$ & $-4.00^{\mathrm{a}}$ & $2000 \mathrm{Q} 1$ & -3.31 & $1992 \mathrm{Q} 4$ & $-4.14^{\mathrm{a}}$ & $2000 \mathrm{Q} 3$ \\
\hline
\end{tabular}

Source: Author's computation using Eviews 9

The breaks recorded in the first quarters of 2004 and 2005 in trade balance also corresponds to the reduction of import duties and removal of VAT on selected imported raw materials which were captured by the 2004 budget statement of Ghana. Following the implementation of this policy the country experienced one of the highest increase in import bill in 2004 compared to developments between 1999 and 2003. Import bill increased by over 32 percent. This contributed to the deficit over 100 percent increase in trade deficit of the country from a deficit of US $\$ 681$ million in 2003 to US $\$ 1,512.7$ million in 2004 (CEPA, 2006). This development might have contributed to the structural break experienced in trade balance in the first quarters of 2004 and 2005.

The Zivot-Andrews test for the capital account identified the fourth and third quarters of 1992 and 2000 as the main periods of structural breaks within the capital account data set. These two periods were both associated with major turning points in the Ghanaian economy. They were both periods that preceded crucial elections that could determine the continued political stability in Ghana. Due to the fear of the unknown after the 1992 and the 2000 elections, the capital account was adversely affected during the periods identified by the test. For example, the capital account which had witnessed an increasing trend since 1987 (increasing from a deficit of US $\$ 17.8$ million in 1986 to US\$237.1 million in 1987 and continued till 1991 where it peaked at US\$391.9 million) declined by 30 percent to about US $\$ 274$ million (Harrigan \& Oduro, 2000).

Similarly, the third quarter of 2000 was associated with declines in the capital account balance of Ghana. The period between July and September was part of the most uncertain periods in the history of the Ghanaian economy as it was unclear whether President Rawlings would hand over power when the opposition party won the general election. This uncertainty probably might have contributed to a decline in the capital account by over 66 percent from US\$726.3 million in 1999 to US $\$ 246.5$ million in 2000 (CEPA, 2002). Foreign Direct Investment also declined by over 50 percent from US $\$ 244$ million in 1999 to US $\$ 115$ million by the end of 2000 . Thus, the uncertainty that surrounded the outcome of the 1992 and 2000 elections had a profound effect on the capital account balance of the country.

Results from the stationarity test indicate that the series employed for the current estimation contain both stationary and non-stationary series. In addition, the structural breaks test also indicate that the measures of external balance have structural breaks in them. The timing of these breaks seems to coincide with major economic, political and policy developments in Ghana. Test unit root test and structural break test suggest that conventional cointegration procedures such as Johansen $(1991,1995)$ which require that all series entering into an equation be non-stationary cannot be used for the present study. In addition, the presence of structural break in our series implies that the conventional cointegration methods cannot be used since such methods are unable to account for endogenous structural breaks.

To overcome these challenges, the analytical model adopted for the present study was based on Autoregressive Distributed Lag (ARDL) or the bounds testing approach to cointegration. This procedure allows for greater degree of flexibility in terms of combining both stationary and non-stationary series in the estimation and can also accommodate extra variables that can represent structural breaks.

\subsection{Cointegration and error correction modelling}

This section presents results from the application of the ARDL procedure presented in Chapter four. Thus, the section applies the Bounds testing to the analytical framework. The study first tested for the presence of cointegrating relationships among the variables of interest after which the long and short run parameters values were estimated.

It is important to note that three additional variables were included during the process of conducting the cointegration test. This was done to control for the structural breaks identified in the preceding section. These variables are mainly dummy variables that captures the structural breaks. For the break identified for Trade Balance, the study included the variable TBDUM with values 1 for periods after the first quarter of 2004 and zero otherwise. For the capital account balance, the study used KADUM. KADUM had values of 1 for periods after the second quarter of third quarter of 2000 and zero otherwise. 
Results of the cointegration tests are presented in Table 3. Where Trade Balance (TB) is the dependent variable (with ODS, ODSS and OSS as part of the explanatory variables), the calculated F-statistic of 3.61 is greater than the critical value at the 5 percent level. The cointegration results were however inconclusive when TB was used as the dependent variable with the log of oil price as part of the dependent variables rather than ODS, ODSS and OSS. The F-statistic of 2.20 , though greater than the lower bound at 5 percent significant level, is less than the upper bound limit. This makes it difficult to determine the existence of long run relationship, hence, the study did not estimate that particular model.

Table 3: Bounds tests for the existence of cointegration

\begin{tabular}{|c|c|c|c|c|c|c|c|c|c|}
\hline \multirow[t]{2}{*}{ Dependent Variable } & \multirow[t]{2}{*}{$\mathrm{K}$} & \multicolumn{6}{|c|}{ Critical Values } & \multirow{2}{*}{$\begin{array}{l}\text { F- } \\
\text { tics }\end{array}$} & \multirow[t]{2}{*}{ Conclusion } \\
\hline & & & $1 \%$ & & $5 \%$ & & $10 \%$ & & \\
\hline & & $\mathrm{I}(0)$ & $\mathrm{I}(1)$ & $\mathrm{I}(0)$ & $\mathrm{I}(1)$ & $\mathrm{I}(0)$ & $\mathrm{I}(1)$ & & \\
\hline $\begin{array}{l}F_{(T B)} \\
\left.=F_{(T B \mid y, r, F B, R E E R, T O T, W Y, O D S, O D S S, O S S, T B D U M}\right)\end{array}$ & 9 & 2.5 & 3.68 & 2.04 & 2.08 & 1.8 & 2.8 & 3.61 & CID \\
\hline$F_{(T B)}=F_{(T B \mid y, r, F B, R E E R, T O T, W Y, L O P, T B D U M)}$ & 7 & 2.73 & 3.90 & 2.17 & 3.21 & 1.92 & 2.89 & 2.20 & ICS \\
\hline $\begin{array}{l}F_{(K A)} \\
\left.=F_{\left(K A \mid, r^{*}, F D I, C A O, R E E R, F B, y, C P I, O D S, O D S S, O S S, K A D U M\right.}\right)\end{array}$ & 10 & 2.41 & 3.61 & 1.98 & 3.04 & 1.76 & 2.77 & 3.15 & CID \\
\hline$F_{(K A)}=F_{\left(K A \mid, r^{*}, F D I, C A O, R E E R, F B, y, C P I, L O P, K A D U M\right)}$ & 8 & 2.62 & 3.77 & 2.11 & 3.15 & 1.85 & 2.85 & 4.61 & CID \\
\hline
\end{tabular}

NOTE: CID implies cointegrated \& ICS implies inconclusive

Source: Author's Computation using Eviews 9

Considering capital account balance models, the cointegration test revealed the existence of cointegration among the variables used in the model at the 5 percent bound. Specifically, the F-statistic for the capital account balance also had an F-statistic of 3.15 and 3.71 for models containing the various measures of oil prices shocks and the log of oil price respectively.

Since the null hypothesis of no cointegration has been rejected for almost all the models, it implies that there exists a long run relationship between oil price shocks and external balance. This also implies an error correction mechanism exist.

\subsection{Long run estimation result}

Given the fact that the study found cointegrating relationship between oil price shocks, the control variables and external balance, the study proceeded to estimate the long run effect of oil price shocks on external balance. Since the study only found cointegrating relationship in five out of the six equations, the study only estimated the long run model for just the five equations. The estimates of the selected ARDL model was based on the Akaike Information Criterion (AIC) for the trade balance model and the Schwarz Bayesian Criterion (SBC) for the Capital account models. The analysis of the long run impact of oil price shocks on external balance would be based on the various measures of external balance identified. The study first analysed the impact of oil price shocks on trade balance, followed by on capital account balance.

\subsection{Trade balance model}

The empirical results of the long run trade balance model (TB1) is presented in Table 4. The results of the study as presented in Table 4 suggest that oil price shocks tend to have differential impact on trade balance of Ghana. Whereas oil demand shock (ODS) had significant (significant at 5 percent level) positive impact on Ghana's trade balance, the impact of oil market specific demand shock (ODSS) was negative (Significant at 10 percent level). Though oil supply shock had the expected sign, it was insignificant. The insignificant long run effect of oil supply shock could be inferred from the impulse response function in the previous section. The result from the impulse response function in the previous section shows that the effect of an oil supply shocks within the sample period has only lasted for a short while, hence this could possibly explain the insignificant impact of oil supply shock on trade balance in Ghana.

Results obtained from the study suggest oil demand shock contribute to improve the trade balance position of the Ghanaian economy in the long run. That is, a unit increase in oil demand shock leads to about 0.41 percentage improvements in Ghana's trade balance position. This is probably because oil demand shock gives an indication of an expansion in global economic activity and hence, such shock would increase demand fall Ghanaian exports such as cocoa, gold, timber among other and this in the long is what contributes to the improvement in the trade balance position of the country.

The results obtained in the present study corroborates with a number of reports of the Bank of Ghana. For example, in 2008 global oil price reached an all-time high of about US\$147 per barrel. This increase in oil price at the time was attributed to high global demand for the commodity due to high economic growth rates in the BRICS. The Bank of Ghana annual report indicated that Ghana's export earnings for 2008 improved. Export earnings of Ghana's economy grew by 26.3 percent (Bank of Ghana, 2009). The growth in exports was mainly fuelled by improved prices in Gold (which increased by an average of 25.9 percent) and timber (which increased 
by 14.6 percent) exports. This implies increases in oil demand that is due to high global demand for industrial commodities tend to improve Ghana's export gains.

On the other hand, oil market specific demand shock tends contribute to the deterioration of the trade balance of Ghana in the long run. Oil market specific demand shocks are mainly not due to increase in economic activities in the global economy, but rather due to precautionary demand for crude oil and speculation in the oil market. As result they may not have significant effect on improving exports of the country rather result in an increase in the value of import even if quantity of oil imports remains the same in the Ghanaian economy. Thus, increase value of imports due to increases in the price crude oil which is also as result of speculation in the oil market would contribute to the deterioration of the trade balance of the country.

The 2006 edition of the Bank of Ghana Annual Report indicated the deterioration in Ghana's trade balance in 2005 was mainly due to high oil imports. Oil imports rose by 41 percent. The increase in oil price was mainly due to increase in the price of the commodity. Average price of oil rose by 43 percent while volume of oil imports also rose by just 3.1 percent. Beidas-Strom and Pescatori (2014) attributed the oil price hikes of 2005 to speculative activities in the oil market. During this period export earnings from cocoa declined by 23.5 percent (CEPA, 2006). Thus, the deterioration of the trade balance after an oil market specific demand shock is due to the fact that import bill of the country increases and since demand for industrial commodities may not have gone up, exports of the country may either decline or remain the same. In either case the trade balance of the economy would deteriorate. The result obtained is consistent with results obtained by Chuku et al. (2011) and Kilian et al. (2009).

From the discussions above and from the regression output, it is obvious that oil price shocks tend to have differential impact on trade balance. That is, the effect of an oil demand shock on trade balance differs from the effect of an oil market specific demand shock on the trade balance of the country. To do this scientifically, the study used the Wald test to test for the differences in the coefficients of oil demand shocks and oil market specific demand shocks. The following null hypothesis was tested

Table 4: Long run estimates

\begin{tabular}{|c|c|c|c|}
\hline Independent Variables & TB1 & KA1 & KA2 \\
\hline \multirow[t]{2}{*}{$L y_{t}$} & $0.386^{b}$ & $-0.492^{b}$ & -0.126 \\
\hline & $(0.151)$ & $(0.207)$ & $(0.215)$ \\
\hline \multirow[t]{2}{*}{$F B_{t}$} & $0.018^{a}$ & 0.131 & 0.074 \\
\hline & $(0.005)$ & $(0.118)$ & $(0.096)$ \\
\hline \multirow{2}{*}{$r_{t}$} & 0.032 & & \\
\hline & $(0.185)$ & & \\
\hline \multirow[t]{2}{*}{$L R E E R_{t}$} & 0.145 & $-0.460^{\mathrm{b}}$ & -0.295 \\
\hline & $(0.107)$ & $(0.224)$ & $(0.193)$ \\
\hline \multirow{2}{*}{ LTOT $_{t}$} & $-0.220^{c}$ & & \\
\hline & $(0.122)$ & & \\
\hline \multirow{2}{*}{$L W Y_{t}$} & $0.965^{\mathrm{a}}$ & & \\
\hline & $(0.259)$ & & \\
\hline \multirow[t]{2}{*}{$O D S_{t}$} & $0.411^{\mathrm{b}}$ & $0.352^{\mathrm{b}}$ & \\
\hline & $(0.198)$ & $(0.144)$ & \\
\hline \multirow[t]{2}{*}{$O D S S_{t}$} & $-0.128^{c}$ & $-0.288^{c}$ & \\
\hline & $(0.048)$ & $(0.107)$ & \\
\hline \multirow[t]{2}{*}{$O S S_{t}$} & -0.754 & $0.122^{\mathrm{b}}$ & \\
\hline & $(0.671)$ & $(0.055)$ & \\
\hline$L O P_{t}$ & & & $\begin{array}{l}-0.180^{\mathrm{b}} \\
(0.084)\end{array}$ \\
\hline$D_{U M T B_{t}}$ & $\begin{array}{c}-0.122^{\mathrm{a}} \\
(0.046)\end{array}$ & & \\
\hline \multicolumn{4}{|l|}{$D U M C A_{t}$} \\
\hline$r_{t}^{*}$ & & $\begin{array}{r}0.041 \\
(0.048)\end{array}$ & $\begin{array}{r}-0.057 \\
(0.039)\end{array}$ \\
\hline \multirow[t]{2}{*}{$F D I_{t}$} & & $0.119^{c}$ & $0.839^{\mathrm{b}}$ \\
\hline & & $(0.065)$ & $(0.407)$ \\
\hline \multirow[t]{2}{*}{$\mathrm{CAO}_{\mathrm{t}}$} & & $-0.292^{\mathrm{c}}$ & $-0.132^{\mathrm{b}}$ \\
\hline & & $(0.149)$ & $(0.063)$ \\
\hline \multirow[t]{2}{*}{$L C P I_{t}$} & & 0.133 & 0.844 \\
\hline & & $(0.142)$ & $(0.997)$ \\
\hline \multirow[t]{2}{*}{$D U M K A_{t}$} & & $-0.359^{b}$ & $-0.293^{a}$ \\
\hline & & $(0.153)$ & $(0.108)$ \\
\hline$C$ & 0.643 & $2.578^{\mathrm{b}}$ & 4.835 \\
\hline
\end{tabular}




\section{(3.381)}

(0.979)

$(5.168)$

Note: a, b and c denotes significance at $1 \%, 5 \%$ and $10 \%$ respectively. Standard Error in parenthesis ()

Source: Estimated by Author using Eviews 9.0

$H_{0}: \alpha_{7}-\alpha_{8}=0$

Where $\alpha_{7}$ and $\alpha_{8}$ are the respective coefficients of ODS and ODSS. Result of the test is presented in Table 5. The Wald test indicates that the null hypothesis stated equation (34) is rejected at one percent level of significance. This clearly indicate that oil price shocks have differential impact on trade balance in Ghana.

Table 5: Results of Wald test

\begin{tabular}{lrrr}
\hline Test Statistic & Value & df & Probability \\
\hline t-statistic & 3.476989 & 85 & 0.0008 \\
F-statistic & 12.08945 & $(1,85)$ & 0.0008 \\
Chi-square & 12.08945 & 1 & 0.0005 \\
\hline
\end{tabular}

Source: Author's computation using Eviews

In relation to other control variables in the trade balance model, the results indicate that income levels tend to have a positive long run effect on the trade balance of Ghana. Thus, a percentage increase in levels of income improves the trade balance of the country by 0.386 percent. The result is consistent with the monetary theories on external balance. The theories indicate that an increase in domestic income levels increases demand for money and hence increase exports and improve trade balance (Duasa, 2007). That is in the long run, high income levels give an indication of improved productivity and as a result exports within the economy also expands. This could be observed in the growth experience of the Ghanaian economy since the start of the twenty first century. For example, with economic growth rate improving from 4.8 percent in 2009 to 7.9 percent in 2010, exports of the economy also grew by 24.7 percent in 2010 from a previous growth of 7.6 percent. Similar trends were recorded in 2011,2012, and 2013. Results obtained in this study is consistent with results obtained by Duasa (2007) for the Malaysian economy.

The long run estimate also indicates the existence of a direct relationship between trade balance and fiscal balance (FB). That is an improvement in fiscal balance (measured by the difference between government revenue and expenditure) contributes to improve the balance of trade of the economy. Conversely, deterioration in the fiscal balance (fiscal deficit) contributes to the deterioration of the balance of trade. Thus results obtained from the present study confirms the twin deficits hypothesis for Ghana. The result suggests that when fiscal balance improves by one percent, trade balance of the economy also improves by 0.018 percent in the long run. Results obtained in the present study is consistent with results obtained by Wiafe (2013) for Ghana and Egwaikhide (1999) for Nigeria. The result is also consistent with results obtained by Nickel and Vansteenkiste (2008) for 22 industrialised countries.

Though interest rate had the expected sign, the result suggest that it has an insignificant long run effect on trade balance. Similarly, the real effective exchange rate was also insignificant in the long run. This suggest that the Marshall-Lerner condition and the J-curve are not held in the long run in the case of Ghana. This result is consistent with a study by Oshota and Adeleka (2015) which established that role of the exchange rate is insignificant in initiating changes in the trade balance in the case of Ghana. The insignificant relationship between the exchange rate and trade balance could be as result of the periodic intervention of the government in the exchange rate market to help stabilise the free fall of the domestic currency at some points in time. Thus, these interventions to help stabilise the domestic currency makes it difficult for the linkage between trade balance and exchange rate to observed in the Ghanaian economy. The insignificant effect of the exchange rate could also be explained by the nature of Ghana's export which is mainly dominated by primary commodities which may not necessarily respond to changes in the exchange rate (Saruni, 2007). Akoto (2016) and Danquah (2008) also obtained the same result for the Ghanaian economy.

The long run estimates also indicate that terms of trade (TOT) has a negative long run effect on trade balance of the Ghanaian economy at 10 percent level of significance. Thus, improvement in the terms of trade tend to have adverse effect on the trade balance of the country. An increase in terms of trade is an indication that export prices are relatively higher than import prices, hence it leads to reduction in exports of the country relative to its imports and this situation results in the deterioration of the trade balance of the economy in the long run.

World income (WY) was found to be positive and significant and this clearly indicated expansion in the world economic activity resulted in improvement in the trade balance position of Ghana in the long run. Specifically, a percentage increase in world income leads 0.97 percentage increase in trade balance. That is higher world income leads to increase in the demand for Ghanaian exports which contribute to increase the trade balance of the country. Akoto (2016) and Danquah (2008) also finds evidence of a positive significant relationship between world income and trade balance. Contrary to the effect of world income, the coefficient of the dummy variable (DUMTB) was found to be negative and significant. The result suggests that the removal of VAT on 
selected imported raw materials in 2004 as overtime had a devastating effect on the economy's trade balance position.

\subsection{Capital account model}

Unlike trade balance model, all the measures of oil price shocks were found to be significant in capital account model. Specifically, oil market demand shock was found to be significant at 5 percent level of significance. The result shows that an increase in the price crude oil that is as result of expansion in global economic activities tend to have positive impact on the capital account balance of the country.

This is expected since expansion in global economic activities gives an indication of an increase in demand for industrial commodities. Since Ghana is also involved in the supply of such commodities, such shocks encourage the inflow foreign investments which in the long run helps to improve the capital balance position of the economy. For example, following the 2008 oil price shock, which have been largely attributed to oil demand shock (see, Kilian, 2009a; Peersman \& Van Robays, 2012), Foreign direct investment in Ghana increased from 5.6 percent of GDP to 9.5 percent of GDP by the end of 2008 . The capital account during this period also improved from 0.76 percent of GDP in 2007 to 1.6 and 2.2 percent of GDP in 2008 and 2009 respectively. Results obtained in the study is consistent with theoretical and empirical arguments made by Kilian et al. (2009).

As expected, oil market specific demand shock had a negative effect on the capital balance position of the country. That is an increase in the price of crude oil that is as a result speculation and precautionary demand in the oil market, would cause a reduction in the capital account balance of the country. It is important to note that Kilian et al. (2009) have argued that the effect of oil market specific demand shock on the capital account depends largely on how the valuation effects manifest themselves in capital gain or losses. Given the fact savings is quite low in Ghana, the composition of ownership of capital is largely foreign in nature, hence an oil market specific shocks could affect the Ghanaian economy in two ways. First such shock would have negative effect on the profitability of firms and as such could encourage investors to halt their investments or even reverse already existing ones.

This could adversely affect the capital account balance position of the country. Secondly, oil market specific shocks also signal investors of a boom in the oil market and in order to take advantage of that would have to invest in oil net exporting countries, this means Ghana would lose out in the inflow of foreign capital to the outflow causing deterioration in the capital account balance of the country. Following the oil price hikes of 2005 (which was mainly due speculative demand for oil-(Beidas-Strom \& Pescatori, 2014)), the inflow of foreign direct investments into Ghana declined from 1.56 percent of GDP to about 1.35 percent of GDP. This confirms the results obtained in the present study. Kilian et al. (2009) also obtained similar results for the US economy. A similar result was obtained in the second model of the capital account (KA2) where the log of crude oil price is included and the various oil market shocks are excluded, the study found that oil price increases tend to have adverse effect on the capital account balance of Ghana. Specifically, a percentage increase in the price of crude oil result in 0.18 percentage reduction in the capital account position of the country.

Contrary to results obtained by Kilian et al. (2009) results from the capital account model indicate that oil supply shock tends to have a positive effect on the capital account balance of Ghana. Thus, oil price increases that is due to supply shock result in improvement in the capital account balance of the country. This was contrary to the expectations of the study. This could probably be explained by the effect of high oil prices on the US dollar.

Researchers have evidence to the fact that high crude oil prices in time past have resulted in the depreciation of the US dollar (see Baffes, Kose, Ohnsorge, \& Stocker, 2015; Feldstein, 2008; Fratzscher, Schneider, \& Van Robays, 2014; Grisse, 2010). The depreciation of the US dollar leads to increase demand for Gold as an alternative store of value and to provide a hedge against the risk of depreciation in value (Wang \& Chueh, 2013; World Gold Council, 2016). With Ghana being among the ten top producers of gold such demand for the commodity is likely to influence the flow of capital to expand production to meet growing demand.

Following the 2003 US invasion of Iraq which gave rise to an oil supply shock for example, growth in mining sector FDI (of which gold dominate) more than quadrupled from a growth of 14.5 percent in 2002 to a growth of 72.8 percent in 2003. Thus, the positive effect of oil supply shocks on the capital account balance is due to the effect of the shock on the US dollar and its subsequent effect on the demand for gold.

In relation to the other control variables in the capital account balance model, the result indicated that on FDI, capital account openness and the dummy for the structural break had significant long run effect on capital account balance. Interest rate differential and the consumer price index had no significant effect on long run capital account balance.

The result specifically indicates that a percentage increase in FDI increases capital account by 0.12 percent, all other things being equal in the long run. This is expected since the inflow of foreign investment only adds up to the capital account rather taking it out. On the other hand, capital account openness was found to have negative effect on the capital account balance. That a unit increase in capital account openness leads to a 0.3 percentage deterioration of the capital account balance of the country. The nature of the Ghanaian economy implies that the kind of FDI the Ghanaian economy would attract would be based on the extraction and primary commodity sector which tends to be very volatile prices in the world market. Hence, in the situation where capital 
account openness increases, investors can easily take away their investments in the long run when prices of the commodities they invested in are down, and this would adversely affect the capital account balance.

\subsection{Short run estimation results}

Once the long run relationship between the variables has been established within the framework of the ARDL approach to cointegration, the study proceeded to estimate the short-run dynamics on the relationship between oil price shocks and external balance. Engle and Granger (1987) argued that, when variables are cointegrated, their dynamic relationship can be specified in an error correction representation in which an error correction term is computed from long run equation is incorporated to capture both short and long run relationships. The coefficient of the ECT gives an indication of the speed with which variables in the model converge to long run equilibrium after a shock. The ECT is expected to be negative and significant. Banerjee, Dolado, and Mestre (1998) have argued that a highly significant error correction term provides further proof of the existence of a long-run relationship. Table 6 presents results from the short run estimates.

Table 6: Estimated short-run dynamic relationships

\begin{tabular}{|c|c|c|c|}
\hline Independent Variables & TB1 & KA1 & KA2 \\
\hline$\Delta \mathrm{TB}_{\mathrm{t}-1}$ & $\begin{array}{r}0.479^{a} \\
(0.072)\end{array}$ & & \\
\hline $\begin{array}{l}\Delta \mathrm{CA}_{\mathrm{t}-1} \\
\Delta \mathrm{CA}_{\mathrm{t}-2}\end{array}$ & & & \\
\hline$\Delta \mathrm{KA}_{\mathrm{t}-1}$ & & $\begin{array}{r}0.856^{\mathrm{a}} \\
(0.077)\end{array}$ & $\begin{array}{r}0.835^{a} \\
(0.078)\end{array}$ \\
\hline$\Delta \mathrm{KA}_{\mathrm{t}-2}$ & & $\begin{array}{r}-0.032 \\
(0.113)\end{array}$ & $\begin{array}{r}0.006 \\
(0.117)\end{array}$ \\
\hline$\Delta \mathrm{KA}_{\mathrm{t}-3}$ & & $\begin{array}{l}-0.325^{a} \\
(0.073)\end{array}$ & $\begin{array}{c}-0.317^{a} \\
(0.077)\end{array}$ \\
\hline$\Delta \mathrm{Ly}_{\mathrm{t}}$ & $\begin{array}{r}0.017 \\
(0.055)\end{array}$ & $\begin{array}{r}-0.244 \\
(2.287)\end{array}$ & $\begin{array}{r}-0.888 \\
(2.469)\end{array}$ \\
\hline$\Delta \mathrm{FB}_{\mathrm{t}}$ & $\begin{array}{r}0.124 \\
(0.082)\end{array}$ & $\begin{array}{r}0.031 \\
(0.026)\end{array}$ & $\begin{array}{r}0.039 \\
(0.028)\end{array}$ \\
\hline$\Delta \mathrm{r}_{\mathrm{t}}$ & $\begin{array}{r}0.018 \\
(0.027)\end{array}$ & & \\
\hline$\Delta$ LREER $_{\mathrm{t}}$ & $\begin{array}{r}0.013^{c} \\
(0.007)\end{array}$ & $\begin{array}{c}0.752^{\mathrm{b}} \\
(0.311)\end{array}$ & $\begin{array}{r}0.672^{\mathrm{a}} \\
(0.252)\end{array}$ \\
\hline$\Delta \mathrm{LTOT}_{\mathrm{t}}$ & $\begin{array}{r}0.390^{\mathrm{a}} \\
(0.093)\end{array}$ & & \\
\hline$\Delta \mathrm{LTOT}_{\mathrm{t}-1}$ & $\begin{array}{l}-0.419 b \\
(0.165)\end{array}$ & & \\
\hline$\Delta \mathrm{LTOT}_{\mathrm{t}-2}$ & $\begin{array}{r}0.252^{\mathrm{b}} \\
(0.101)\end{array}$ & & \\
\hline$\Delta \mathrm{LWY}_{\mathrm{t}}$ & $\begin{array}{r}0.074^{c} \\
(0.043)\end{array}$ & & \\
\hline$\Delta \mathrm{ODS}_{\mathrm{t}}$ & $\begin{array}{r}-0.010 \\
(0.016)\end{array}$ & $\begin{array}{r}0.025^{a} \\
(0.008)\end{array}$ & \\
\hline$\Delta \mathrm{ODS}_{\mathrm{t}-1}$ & $\begin{array}{l}-0.065^{a} \\
(0.022)\end{array}$ & & \\
\hline$\Delta \mathrm{ODS}_{\mathrm{t}-2}$ & $\begin{array}{l}-0.090^{\mathrm{a}} \\
(0.020)\end{array}$ & & \\
\hline$\Delta \mathrm{ODS}_{\mathrm{t}-3}$ & $\begin{array}{l}-0.048^{a} \\
(0.015)\end{array}$ & & \\
\hline$\Delta \mathrm{ODSS}_{\mathrm{t}}$ & $\begin{array}{r}0.003 \\
(0.068)\end{array}$ & $\begin{array}{l}-0.229 a \\
(0.055)\end{array}$ & \\
\hline$\Delta \mathrm{ODSS}_{\mathrm{t}-1}$ & $\begin{array}{l}-0.314^{b} \\
(0.169)\end{array}$ & & \\
\hline$\Delta \mathrm{ODSS}_{\mathrm{t}-2}$ & $\begin{array}{l}-0.612^{a} \\
(0.142)\end{array}$ & & \\
\hline$\Delta \mathrm{ODSS}_{\mathrm{t}-3}$ & $\begin{array}{r}0.478^{a} \\
(0.122)\end{array}$ & & \\
\hline$\Delta \mathrm{OSS}_{\mathrm{t}}$ & $\begin{array}{r}-0.008 \\
(0.020)\end{array}$ & $\begin{array}{r}0.191^{\mathrm{a}} \\
(0.049)\end{array}$ & \\
\hline$\Delta \mathrm{OSS}_{\mathrm{t}-1}$ & -0.023 & & \\
\hline
\end{tabular}




\begin{tabular}{|c|c|c|c|}
\hline$\Delta \mathrm{OSS}_{\mathrm{t}-2}$ & $\begin{array}{r}(0.020) \\
0.031 \\
(0.21)\end{array}$ & & \\
\hline $\mathrm{LOP}_{\mathrm{t}}$ & & & $\begin{array}{r}-0.317 \\
(0.222)\end{array}$ \\
\hline DUMTB $_{\mathrm{t}}$ & $\begin{array}{r}-0.350 \\
(0.861)\end{array}$ & & \\
\hline $\begin{array}{l}\text { DUMCA }_{t} \\
\Delta \mathrm{r}_{\mathrm{t}}^{*}\end{array}$ & & $\begin{array}{r}0.041^{\mathrm{a}} \\
(0.010)\end{array}$ & $\begin{array}{r}0.024^{b} \\
(0.010)\end{array}$ \\
\hline$\Delta \mathrm{r}_{\mathrm{t}-1}^{*}$ & & $\begin{array}{l}-0.052^{\mathrm{a}} \\
(0.041)\end{array}$ & \\
\hline$\Delta \mathrm{FDI}_{\mathrm{t}}$ & & $\begin{array}{c}0.385^{\mathrm{a}} \\
(0.144)\end{array}$ & $\begin{array}{r}0.388^{b} \\
(0.152)\end{array}$ \\
\hline$\Delta \mathrm{CAO}_{\mathrm{t}}$ & & $\begin{array}{r}0.074^{b} \\
(0.035)\end{array}$ & $\begin{array}{r}0.493^{\mathrm{c}} \\
(0.284)\end{array}$ \\
\hline$\Delta \mathrm{LCPI}_{\mathrm{t}}$ & & $\begin{array}{r}-0.010 \\
(0.191)\end{array}$ & $\begin{array}{r}-0.026 \\
(0.040)\end{array}$ \\
\hline$\Delta \mathrm{LCPI}_{\mathrm{t}-1}$ & & $\begin{array}{l}-0.112^{\mathrm{a}} \\
(0.017)\end{array}$ & $\begin{array}{l}-0.276^{\mathrm{a}} \\
(0.040)\end{array}$ \\
\hline$\Delta \mathrm{LCPI}_{\mathrm{t}-2}$ & & $\begin{array}{l}-0.110^{\mathrm{a}} \\
(0.019)\end{array}$ & $\begin{array}{l}-0.291^{\mathrm{a}} \\
(0.043)\end{array}$ \\
\hline DUMKA $_{\mathrm{t}}$ & & $\begin{array}{r}-0.340 \\
(0.306)\end{array}$ & $\begin{array}{r}-0.456 \\
(0.322)\end{array}$ \\
\hline $\mathrm{C}$ & & & \\
\hline $\mathrm{ECT}_{\mathrm{t}-1}$ & $\begin{array}{c}-0.090^{\mathrm{a}} \\
(0.015)\end{array}$ & $\begin{array}{l}-0.107^{a} \\
(0.015)\end{array}$ & $\begin{array}{l}-0.138^{a} \\
(0.021)\end{array}$ \\
\hline
\end{tabular}

Note: a, b and c denotes significance at 1\%, 5\% and 10\% respectively. Standard Error in parenthesis () Source: Estimated by Author using Eviews 9.0

From Table 6, the coefficient of the lagged of error correction term $\left(E C T_{t-1}\right)$ is negative and significant at one percent level for all the models estimated (TB1, KA1 and KA2). For the trade balance model (TB1) the error correction term indicates that about 9 percent of the deviations from the long run balance of trade position caused by a shock in the previous quarter is corrected in the current quarter. The capital account balance models (KA1 and KA2) seem to have the fastest speed of adjustment. The results indicate that about 10.7 and 13.8 percent of the deviations from long run capital account position cause by previous quarter's shock is corrected in the current quarter for models KA1 and KA2 respectively.

The trade balance takes about 12 quarters ( 3 years) to revert to its long run equilibrium position after a shock. This is relatively high when compared to the capital account balance which on average takes about 8 quarters (2 years) to revert to long run equilibrium after a shock. The differences in the speed of adjustment could be as results of the various components of each measure of external balance. It would take a lot of productive man hours to increase output in order to increase exports to restore balance in trade when an oil price shock for example increases trade deficit in the economy. For capital account, it involves activities that does not require a lot of time to materialised hence its faster speed of adjustment. In relation to the external balance as a whole it takes about 9 quarters ( 2 years three months) to restore to long run equilibrium after a shock to the external balance of the country. This could probably explain why the International Monetary Fund (IMF) approved a threeyear programme for the Government of Ghana to help improve the Balance of Payment challenges the Ghanaian economy was facing.

\subsection{Short run effects of oil price shocks on external balance}

The results of the trade balance model indicate that oil demand shock and oil market specific demand shocks are the only oil market variables that affect trade balance in the short run. Oil supply shock was found to be insignificant. The contemporaneous effect of the two variables (ODS and ODSS) was found not have significant effect on trade balance. The capital account balance on the other hand was affected by the contemporaneous effect of oil demand shock, oil market specific shock and oil supply shock. The difference in the timing of the effect could be due to the fact that capital markets reacts quickly to information than the goods market.

Considering the capital account balance, the result indicates that a unit increase in oil market shock will cause the capital account balance to improve by 0.03 percentage point. The positive link between oil demand shock and the capital account could be due to the fact that oil demand shock signals increase in global economic activities which implies increased demand for industrial commodities (see Kilian, 2009a) of which Ghana is a key producer. Hence, the capital account responds positively probably due to influx of FDI to expand domestic 
production of industrial commodities such as gold, cocoa, timber etc. For example, following the oil demand shock of 2008 which resulted in oil prices reaching an all-time high of about US\$147 per barrel by July 2008, Ghana's capital account balance, during the third quarter of 2008 improved by US\$801.43 million dollars (Bank of Ghana, 2008). The Bank of Ghana attributed this improvement to improvement in net receipts which reflected proceeds of US $\$ 900$ million obtained from the sale of Ghana Telecom as well as the FDI inflows of US\$461.22 million.

The result of the study also shows that trade balance is affected by the lag of oil demand shocks at one. Specifically, a unit increase in oil demand shock would cause trade balance to deteriorate by 0.07 percentage point. The deterioration in the trade balance could be due to increase in the cost of crude oil which contribute increase the value of imports even when the quantity of oil imported into the country remains the same. For example the trade balance position of Ghana deteriorated by 28.7 percent in 2008 mainly due to the oil demand shock of 2008 (CEPA, 2009). Das et al. (2014) maintain that such shocks contribute to the transfer of income from oil importing economies to oil exporting economies. The adverse effect of oil demand shock on trade balance persist till the third quarter. This is probably due to the time that is required to increase domestic export to counter the effect of the oil price shock. It is therefore not surprising that the influx of FDI in response to expansion in global demand for industrial commodities, as indicated by the effect of ODS on the capital account, starts yielding results in the long run where the effect of ODS on trade balance turns positive.

The effect of oil market specific shock was only felt on the trade balance after the first quarter. As expected, oil price increase that is due precautionary demand for the commodity leads to the deterioration of the trade balance a quarter after the shock and this persist till the end of the second quarter after the shock. The effect oil market specific shock on trade balance turns positive in the third quarter after the shock. This could be the result of the effect of oil price increase on the depreciation of the US dollar as indicated earlier in the long run analysis. Once investors decide to reduce the risk of loss of value the is coming from the depreciation of the US dollar, they resort to the use of Gold as a store of value. This causes an increase in demand for Gold in Ghana, which contribute to reduce the trade deficit that is created by high oil imports.

Oil supply shocks was found not to have significant effect on trade balance. However, it had a positive significant effect on capital account balance. The positive impact of oil supply shock could be explained by investment gains into the mining industrial due to an anticipated increased demand for precious metal as an alternative store of value following an anticipated depreciation of the US dollar. In addition, since most oil supply shocks are usually sparked by conflicts in oil exporting economies, investors may find it inappropriate to invest in such economies and would want a more stable economy to invest, hence, the positive relationship between oil supply shock and capital account balance in Ghana.

The results of the dependent variable lagged one period indicates that improvements in trade balance and capital account balance persist for at least one quarter. Thus, improvements in the external balance position of the country in the previous quarter tend to have positive effect on external balance. However, this turns negative when it persists for more than one quarter. This evident by the effect of $\Delta K A_{t-2}$ and $\Delta K A_{t-3}$ on capital account balance in model KA1 and KA2. The negative effect of the lagged measures of external balance could be due to the fact that continuous improvements in capital account balance may lead to the appreciation of the local currency which would make imports relatively cheaper when compared to exports.

The short run estimates indicated that income level, fiscal balance and short term interest rate had effect on all the measures of external balance. The dummy variable (DUMTB) that was included in the various models to capture the effect of structural break identified were insignificant in the short run.

The result of the short run estimate reveals that the appreciation of the domestic currency against its major trading partners tend to have positive effect on external balance. Specifically, a percentage increase in the real effective exchange rate improves trade balance (TB1) and capital account balance (KA1) by 0.013 , and 0.75 percent respectively. This implies that depreciation of the exchange rate would result in the deterioration of the external balance position of the country. The results seem to satisfy the first condition of the J-curve effect in which trade balance worsens initially after depreciation. The study could not fully confirm the J-curve effect in the case of Ghana since the coefficient real effective exchange rate, though negative for most of the measures of external balance, was insignificant. Akoto (2016) using nominal exchange rate arrived at the same conclusion for Ghana.

The contemporaneous effect of terms of trade was found to be significant and positive at one percent level of significance. That is, a percentage increase in the terms of trade resulted in a 0.39 percentage improvement in the trade balance of the country. The improvements in the trade balance would largely be as a result of improve values of exports (even when volume of exports remains the same) due to higher prices. The lag of terms of trade tend to have an adverse effect on trade balance due to the fact that over time exports of the country becomes relatively expensive as trade balance improves and imports becomes cheaper which tends to have negative effect on the trade balance. The deterioration of the trade balance due to increase in imports that resulted from relatively cheaper import could contribute to the depreciation of the local currency which would later make imports relatively expensive and this improves the terms of trade. Exports also expands as result of this. This is why the effect of the third lag of terms of trade on trade balance terms from negative to positive. 
As expected, improvement in world income leads to increase in demand for Ghanaian exports. The short run estimate confirms this as a percentage increase in world income leads to 0.07 percentage improvement in the trade balance of the country.

The short run estimates also reveal that interest rate differential has a positive effect on the capital account balance of the country. The result specifically indicates that an increase in interest rate differential leads to improvement in the capital account by 0.04 and 0.2 percent for KA1 and KA2 respectively. That is high domestic interest rate serves as motivation for individuals who wish to earn more on their investment, hence they invest in domestic investment instrument which goes to improve capital account balance. Liyanasge (2016) obtained similar results for the Sri-Lankan economy.

As expected the coefficient of FDI is positive and significant at one percent. The contemporaneous effect of FDI indicates that a percentage increase in the inflow of foreign direct investment leads to a 0.38 percentage increase in the capital account. The effect of capital account openness on capital account balance was also found to be positive. Indicating that the greater the level of openness, the higher the inflow of capital in the short run. The results from the long run estimates revealed the effect of capital account openness on capital account is not lasting, it turns negative in the long run. The capital account model also shows that inflation is inimical to improvements in the capital account balance. This is because a percentage increase in the lag of inflation leads to 0.11 reduction in the capital account balance. This situation persists till the second quarter. This is probably due to the effect of inflation on real interest rate. since increase inflation implies reduction in the real interest rate of the country, high inflation implies lower real returns on investments which hampers the inflow of foreign capital into the Ghanaian economy. Results obtained in this study is consistent with results obtained by Arshad, Majeed and Shah (2012) and Liyanage (2016).

\subsection{Model diagnostics and stability tests}

Since estimated parameters of time series data could vary over time (Hansen, 1992), it is critical to conduct parameter tests in order to check for model specification errors that may arise due to unstable parameters and subsequently lead to biased estimates.

Result from several diagnostic test indicate that over 90 percent of the variations external balance (Trade Balance and Capital Account Balance) are explained by variations in oil price shocks and the variations in the other control variables. The F-test for the overall significance of the estimated external balance model indicates that all the estimated models of external balance are significant at one percent. This implies that, explanatory variables employed for the current estimation are good predictors of external balance in Ghana.

Table 7: Model goodness of fit and diagnostics

\begin{tabular}{lrrr}
\hline & & & Model \\
\hline Test Statistic & TB1 & KA1 & KA2 \\
\hline R-Squared & 0.977 & 0.953 & 0.912 \\
Adjusted R-Square & 0.920 & 0.931 & 0.890 \\
F-Statistic & $137.945(0.00)$ & $538.21(0.00)$ & $527.50(0.00)$ \\
Durbin-Watson & 1.898 & 2.24 & 1.960 \\
Serial Correlation & $0.999(0.61)$ & $1.403(0.25)$ & $0.027(0.97)$ \\
Normality & $2.297(0.32)$ & $0.724(0.696)$ & $0.18(0.91)$ \\
Functional Form & $2.235(0.14)$ & $0.029(0.86)$ & $0.493(0.49)$ \\
Heteroscedasticity & $1.161(0.30)$ & $1.409(0.15)$ & $2.361(0.06)$ \\
\hline
\end{tabular}

Source: Author's Computation

The post estimation test on the residual term for the estimated five models indicates the absence of serial correlation in all five models. Also, the test on the residual also indicated the absence of heteroscedasticity in four out of the five models. The test on heteroscedasticity on the KA2 model however indicated that the error term is heteroscedastic at 10 percent level of significance. Test for the normality of the error terms for all the estimated five models also shows that the errors are normally distributed. The estimated models also pass the Ramsey RESET test for correct specification of the model.

In order to check the stability of the coefficients of the models estimated, we used the CUSUM and CUSUM Square of recursive residuals stability test as suggested by Pesaran and Pesaran (1997). The test is based on the null hypothesis the coefficient vector is the same in every period. An examination of the plot of CUSUM and CUSUMSQ of recursive residual stability test in Appendix B indicates that all the coefficients of the estimated models are stable over the study period since they are within the 5 percent critical bounds.

\section{Conclusion}

We examine the identify the how these oil price shocks affect Ghana's external balance position. The results revealed that oil demand shocks tend to have a positive long run effect on external balance and oil market specific 
demand shock was also found to negative long run effect. Whereas oil supply shock was found to have a negative impact on trade balance and current account balance, its effect on capital account balance was positive.

\section{References}

Akoto, L. (2016). An Empirical Analysis of the Determinants of Trade Balance in Post-Liberalisation Ghana (MPhil Thesis). Kwame Nkrumah University of Science and Technology, Kumasi. Retrieved from http://ir.knust.edu.gh/handle/123456789/9303

Arshad, M. U., Majeed, S., \& Shah, A. (2012). The Determinants of Capital Inflow in Developing Economies An Empirical Study of Pull Factors. Journal of Basic and Applied Scientific Research, 2(10), 9764-9769.

Baffes, J., Kose, M. A., Ohnsorge, F., \& Stocker, M. (2015). The great plunge in oil prices: Causes, consequences, and policy responses. Consequences, and Policy Responses (June 2015). Retrieved from http://papers.ssrn.com/sol3/papers.cfm?abstract_id=2624398

Banerjee, A., Dolado, J., \& Mestre, R. (1998). Error-correction mechanism tests for cointegration in a singleequation framework. Journal of Time Series Analysis, 19(3), 267-283.

Bank of Ghana. (2008a). Bank of Ghana Quarterly Bulletin (Quarterly Bulletin No. 2008Q2). Accra: Bank of Ghana.

Bank of Ghana. (2008b). Quarterly Bulletin-July-September. Accra: Bank of Ghana.

Bank of Ghana. (2009). Annual Report 2008. Accra: Bank of Ghana.

Bank of Ghana. (2012). Annual Report 2011. Accra: Bank of Ghana.

Bank of Ghana. (2015). Annual Report 2014 (pp. 18-20). Accra: Bank of Ghana.

Beidas-Strom, S., \& Pescatori, A. (2014). Oil Price Volatility and the Role of Speculation. Retrieved from https://papers.ssrn.com/sol3/papers.cfm?abstract_id $=2561232$

Bodenstein, M., Erceg, C. J., \& Guerrieri, L. (2011). Oil shocks and external adjustment. Journal of International Economics, 83(2), 168-184.

Brafu-Insaidoo, W. G., \& Biekpe, N. (2014). Determinants of foreign capital flows: The experience of selected SubSaharan African countries. Journal of Applied Economics, 17(1), 63-88.

Cantah, W. G., Brafu-Insaidoo, W. G., Wiafe, A. E., \& Adams, A. (2016). FDI and Trade Policy Openness in SubSaharan Africa. Eastern Economic Journal. https://doi.org/10.1057/eej.2016.9

CEPA. (2002). Accra: Centre for Policy Analysis.

CEPA. (2006). Ghana Economic Review and Outlook (No. No. 11). Accra: Centre for Policy Analysis.

CEPA. (2009). Ghana Economic Review and Outlook 2009. Accra: Centre for Policy Analysis.

Chuku, C. A., Akpan, U. F., Sam, N. R., \& Effiong, E. L. (2011). Oil price shocks and the dynamics of current account balances in Nigeria. OPEC Energy Review, 35(2), 119-139.

Danquah, B. A. (2008). The Effects of Exchange Rate on Ghana's External Trade (Doctorial Thesis). Kwame Nkrumah University of Science and Technology. Retrieved from http://ir.knust.edu.gh/handle/123456789/579

Das, S., Bose, S., \& Bhanumurthy, N. R. (2014). Oil Price Shock, Pass-Through Policy and its Impact on India. In Market, Regulations and Finance (pp. 231-253). Springer. Retrieved from http://link.springer.com/chapter/10.1007/978-81-322-1795-4_13

Duasa, J. (2007). Determinants of Malaysian trade balance: An ARDL bound testing approach. Global Economic Review, 36(1), 89-102.

Edwards, S. (1990). Capital flows, foreign direct investment, and debt-equity swaps in developing countries. National Bureau of Economic Research. Retrieved from http://www.nber.org/papers/w3497

Egwaikhide, F. O. (1999). Effects of budget deficit on trade balance in Nigeria: a simulation exercise. African Development Review, 11(2), 265-289.

Energy Commission of Ghana. (2016). National Energy Statistics (2006-2016). Accra: Energy Commission of Ghana.

Engle, R. F., \& Granger, C. W. (1987). Co-integration and error correction: representation, estimation, and testing. Econometrica: Journal of the Econometric Society, 251-276.

Feldstein, M. (2008). The Dollar and the Price of Oil. National Buraue of Economic Research Working Papers. Retrieved from http://www.nber.org/feldstein/dollarandpriceofoil.syndicate.08.pdf

Fratzscher, M., Schneider, D., \& Van Robays, I. (2014). Oil prices, exchange rates and asset prices. Retrieved from http://papers.ssrn.com/sol3/papers.cfm?abstract_id=2442276

Goldstein, M., \& Khan, M. S. (1985). Income and price effects in foreign trade. Handbook of International Economics, 2, 1041-1105.

Grisse, C. (2010). What Drives the Oil-Dollar Correlation? Unpublished Manuscript.

Gujarati, D. N. (2009). Basic econometrics. Tata McGraw-Hill Education. 
Hansen, B. E. (1992). Tests for parameter stability in regressions with I (1) Processes. Journal of Business and Economic Statistics, 10(3), 321-335.

Harrigan, J., \& Oduro, A. (2000). Exchange rate policy and the Balance of payments. Economic Reforms in Ghana: The Miracle and the Mirage, Oxford: James Currey.

Huntington, H. G. (2015). Crude Oil Trade and Current Account Deficits. Energy Economics, 50.

IEA. (2016). International Energy Agency Consumption of Oil Products. Retrieved 19 December 2016, from https://www.iea.org/stats/WebGraphs/GHANA1.pdf

Johansen, S. (1991). Estimation and hypothesis testing of cointegration vectors in Gaussian vector autoregressive models. Econometrica: Journal of the Econometric Society, 1551-1580.

Johansen, S. (1995). Likelihood-based inference in cointegrated vector autoregressive models. Oxford University Press on Demand.

Kilian, L. (2009). Not All Oil Price Shocks Are Alike: Disentangling Demand and Supply Shocks in the Crude Oil Market. The American Economic Review, 99(3), 1053-1069.

Kilian, L., Rebucci, A., \& Spatafora, N. (2009). Oil shocks and external balances. Journal of International Economics, 77(2), 181-194.

Liyanage, E. (2016). Determinants of Capital Inflows: Evidence from Sri Lanka. Central Bank of Sri Lanka. Retrieved from http://ss.sljol.info/articles/abstract/10.4038/ss.v44i1-2.4692/

Mucuk, M., Gerçeker, M., \& Ay, A. (2013). The Relationship between International Oil Prices and Current Account Deficit: The Case of Turkey. Presented at the International Conference on Eurasian Economies.

Nickel, C., \& Vansteenkiste, I. (2008). Fiscal policies, the current account and Ricardian equivalence. Retrieved from https://papers.ssrn.com/sol3/papers.cfm?abstract_id=1243262

Oshota, S. O., \& Adeleka, I. A. (2015). Determinants of the Current Account Balance in Nigeria, Ghana and Cote'd'Ivoire. Acta Universitatis Danubius. ØEconomica, 11(3). Retrieved from http://www.journals.univdanubius.ro/index.php/oeconomica/article/view/2774

Peersman, G., \& Van Robays, I. (2012). Cross-country differences in the effects of oil shocks. Energy Economics, 34(5), 1532-1547.

Pesaran, M. Hashem, Shin, Y., \& Smith, R. J. (2001). Bounds testing approaches to the analysis of level relationships. Journal of Applied Econometrics, 16(3), 289-326.

Pesaran, Mohammad Hashem, \& Pesaran, B. (1997). Working with Microfit 4.0: interactive econometric analysis; [Windows version]. Oxford University Press.

Rose, A. K. (1991). The role of exchange rates in a popular model of international trade: Does the 'MarshallLerner'condition hold? Journal of International Economics, 30(3-4), 301-316.

Rose, A. K., \& Yellen, J. L. (1989). Is there a J-curve? Journal of Monetary Economics, 24(1), 53-68.

Sakyi, D., \& Opoku, O. E. E. (2016). The twin deficits hypothesis in developing countries: Empirical evidence for Ghana (Technical No. S-33201-GHA-1). International Growth Centre.

Saruni, M. (2007). Determinants of the Trade Balance in Tanzania, 1970-2002. Awarded Theses, 69.

Wang, Y. S., \& Chueh, Y. L. (2013). Dynamic transmission effects between the interest rate, the US dollar, and gold and crude oil prices. Economic Modelling, 30, 792-798.

Wiafe, E. A. (2013). The Link between Fiscal Deficit and Current Account in Ghana (Unpublished Thesis). University of Cape Coast, Cape Coast.

World Gold Council. (2016). What is Driving the Current Demand for Gold. State Street Global Advisors. 


\section{Appendix}

Stability test for model TB1

Figure B1a: Plot of cumulative sum of recursive residuals

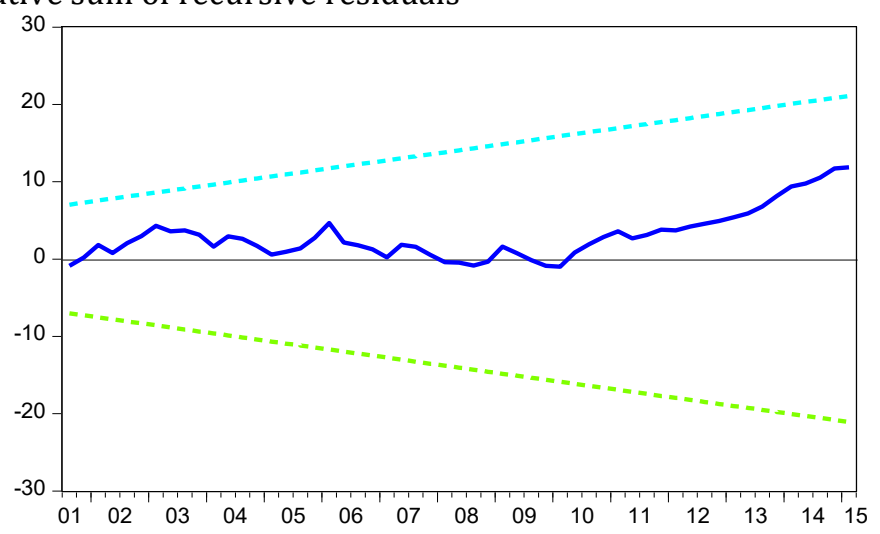

- CUSUM $=--5 \%$ Significance

Figure B1b: Plot of cumulative sum of squares of recursive residuals

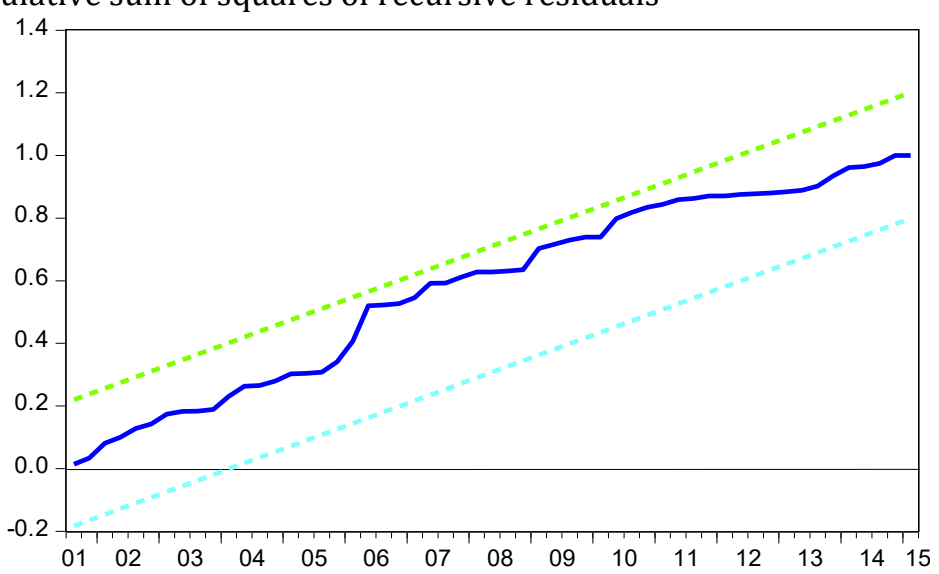

Stability Test for model KA1

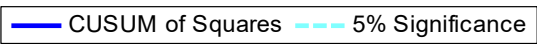

Figure B3a: Plot of cumulative sum of recursive residuals

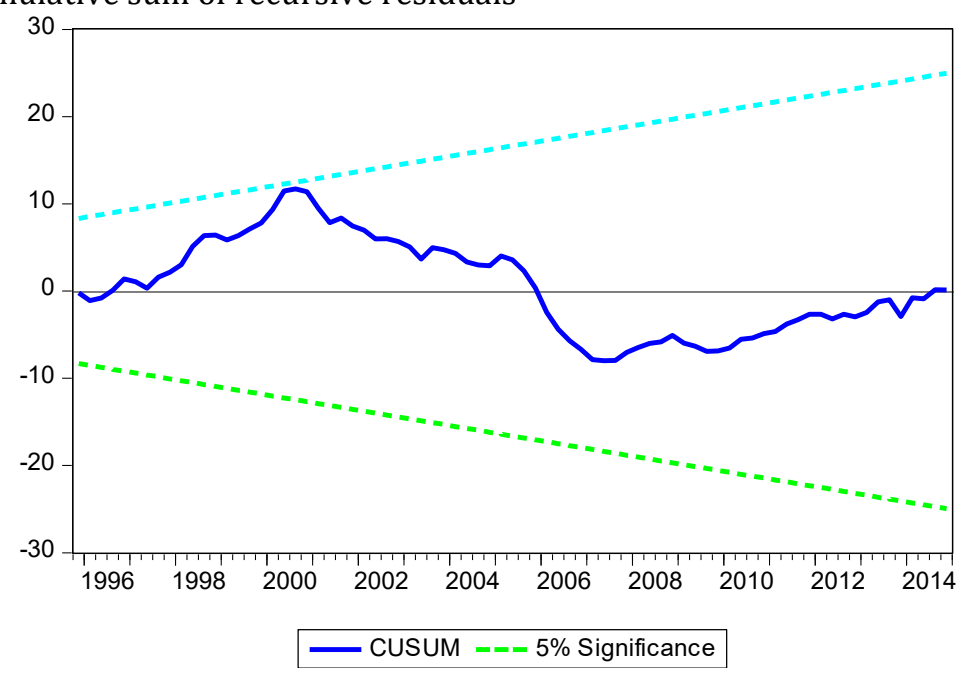


Figure B3b: Plot of cumulative sum of squares of recursive residuals

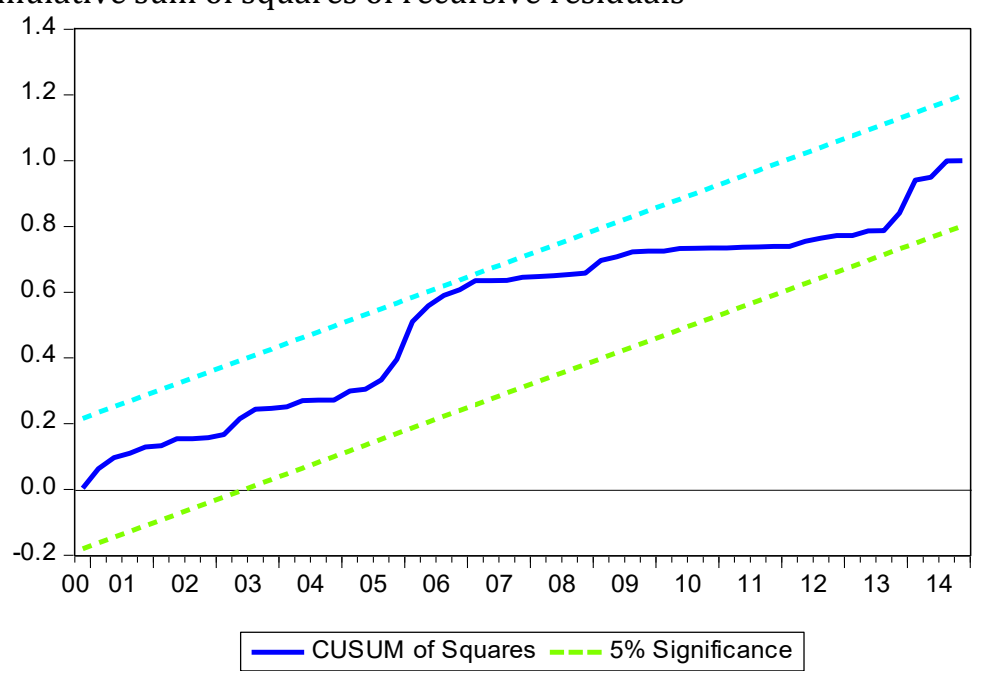

Stability test for model KA2

Figure B4a: Plot of cumulative sum of recursive residuals

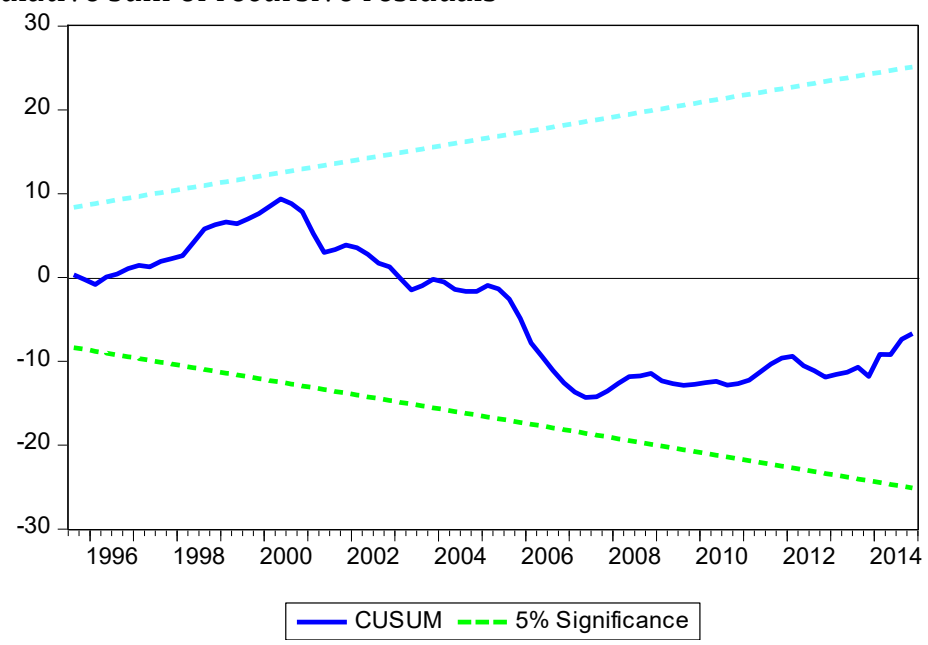

Figure B4b: Plot of cumulative sum of squares of recursive residuals

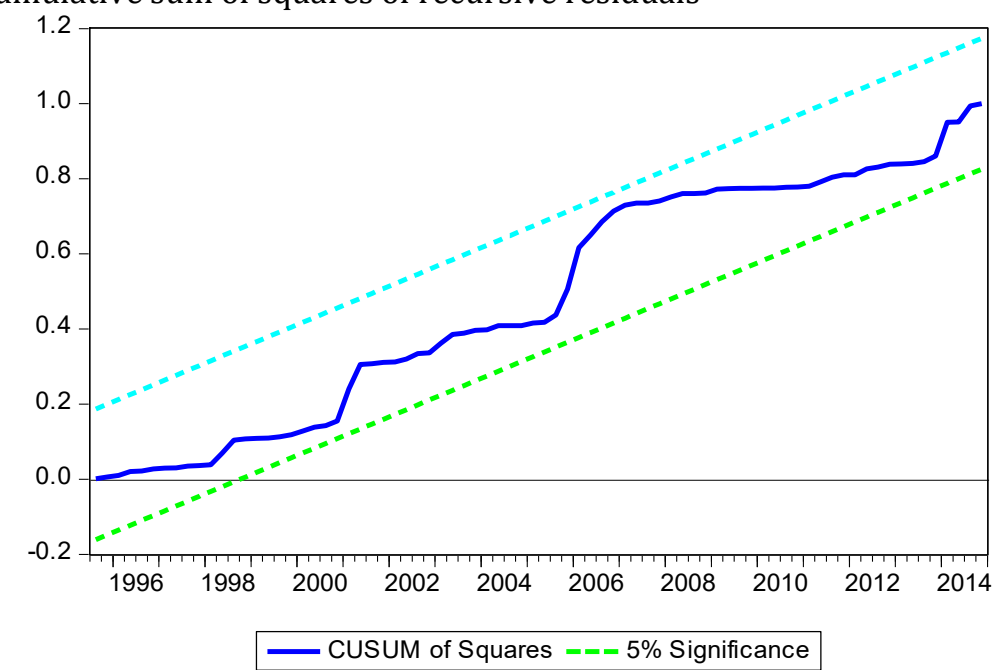

Source: Author's Computation 